\title{
Zespół BAS*
}

\section{Ocena sprawozdania ogólnego Komisji Europejskiej z działalności Unii Europejskiej ${ }^{1}$}

\begin{abstract}
Assessment of the general report of the European Commission on the activities of the European Union: The article contains description of the subject matter of the European Commission's document, as well as its substantive and legal assessment. The authors point out that the report is not controversial. The document issued by the European Commission is correct from the legal point of view and conforms to the adopted work program. Most of the issues described in the report were raised in the course of the year in the form of detailed documents.
\end{abstract}

\section{Keywords: report, European Union, European Commission}

Słowa kluczowe: $\quad$ sprawozdanie, Unia Europejska, Komisja Europejska

* Jolanta Adamiec, doktor nauk ekonomicznych, ekspert BAS ds. systemu gospodarczego•jolanta.adamiec@sejm.gov.pl

Konrad Kuszel, ekspert BAS ds. legislacji, konrad.kuszel@sejm.gov.pl • https://orcid.org/0000-0001-9664-4836

Mirosław Sobolewski, ekspert BAS ds. systemu gospodarczego • miroslaw.sobolewski@ sejm.gov.pl - https://orcid.org/0000-0003-4480-1478

Zofia Szpringer, doktor nauk ekonomicznych, naczelnik Wydziału Analiz Społecznych i Ekonomicznych BAS • zofia.szpringer@sejm.gov.pl • https://orcid.org/0000-0002-8265-4440

Adrian Grycuk, ekspert BAS ds. systemu gospodarczego • adrian.grycuk@sejm.gov.pl . https://orcid.org/0000-0002-3727-0456

Jacek Krzak, ekspert BAS ds. systemu gospodarczego - jacek.krzak@sejm.gov.pl . https://orcid.org/0000-0002-1409-8251

Piotr Russel, doktor nauk ekonomicznych, Szkoła Główna Handlowa, Kolegium Zarządzania i Finansów, ekspert BAS ds. systemu gospodarczego - piotr.russel@sejm.gov.pl • https://orcid.org/0000-0001-5749-8952

Kamilla Marchewka-Bartkowiak, doktor hab. nauk ekonomicznych, prof. Uniwersytetu Ekonomicznego w Poznaniu, Wydział Ekonomii, ekspert BAS ds. finansów publicznych kamilla.marchewka-bartkowiak@sejm.gov.pl • https://orcid.org/0000-0001-5703-4189

$1 \quad$ Opinia w sprawie sprawozdania Komisji Europejskiej z 15.2.2018: UE w 2018 r. Sprawozdanie ogólne z działalności Unii Europejskiej (C(2019) 1115 final) sporządzona 2 kwietnia 2019 r. na zlecenie przewodniczącego Komisji do Spraw Unii Europejskiej; BAS-WASiE-WAPM 375/19. 
Paweł Bachmat, asystent w Instytucie Wymiaru Sprawiedliwości, ekspert BAS ds. legisla-

cji • pawel.bachmat@sejm.gov.pl • https://orcid.org/0000-0003-3511-5425

Paweł Kościelny, ekspert BAS ds. legislacji • pawel.koscielny@sejm.gov.pl •

https://orcid.org/0000-0002-4070-5107

Dobromir Dziewulak, doktor nauk humanistycznych, Uniwersytet Warszawski, ekspert

BAS ds. międzynarodowych - dobromir.dziewulak@sejm.gov.pl .

https://orcid.org/0000-0002-7974-8024

Łukasz Żołądek, ekspert BAS ds. międzynarodowych . lukasz.zoladek@sejm.gov.pl .

https://orcid.org/0000-0001-5247-6228

Marek Jaśkowski, doktor nauk prawnych, adiunkt na Uniwersytecie Kardynała Stefana

Wyszyńskiego, ekspert BAS ds. legislacji - marek.jaskowski@sejm.gov.pl .

https://orcid.org/0000-0001-6598-810X

\section{Opinia merytoryczna}

\section{Przedmiot dokumentu UE}

\section{- Treść dokumentu UE}

Przedmiotem dokumentu jest sprawozdanie ogólne z działalności Unii Europejskiej w roku 2018. Komisja Europejska corocznie sporządza sprawozdanie za rok poprzedni, w którym przedstawia stan wykonania zadań przyjętych w rocznym planie pracy ${ }^{2}$. Obecne sprawozdanie jest ostatnim takim dokumentem Komisji Europejskiej w jej obecnej kadencji. Wskazuje więc nie tylko realizację postawionych priorytetów w roku 2018, ale także szanse ich realizacji do końca obecnej perspektywy finansowej, oraz informuje o przyjętych nowych działaniach, inicjatywach i przepisach. Ponadto zawiera kluczowe informacje dotyczące przyszłego długoterminowego budżetu na lata 2021-2027³. Na końcu sprawozdania poruszone są kwestie związane z wystąpieniem Zjednoczonego Królestwa z Unii Europejskiej.

Działania podejmowane przez Komisję koncentrują się wokół dziesięciu priorytetów wskazanych w agendzie na rzecz zatrudnienia, wzrostu gospodarczego, sprawiedliwości i demokratycznych zmian, przyjętej na początku obecnej kadencji Komisji pod przewodnictwem Jean-Claude Junckera ${ }^{4}$. Priorytety te zdefiniowane były następująco:

2 Program prac Komisji na 2018 r. Plan działania na rzecz bardziej zjednoczonej, silniejszej i bardziej demokratycznej Unii, COM(2017) 650 final.

3 Informacje te przypisane są do każdego z rozdziałów, z wyjątkiem rozdz. 6 - Zrównoważona i postępowa polityka handlowa w celu wykorzystania możliwości płynących z globalizacji oraz rozdz. 10 - Unia demokratycznych zmian.

4 Jean-Claude Juncker, Nowy początek dla Europy: Mój program na rzecz zatrudnienia, wzrostu, sprawiedliwości oraz zmian demokratycznych. Wytyczne polityczne na następną kadencje Komisji Europejskiej, przemówienie inauguracyjne wygłoszone podczas sesji plenarnej Parlamentu Europejskiego, Strasburg, 15 lipca 2014 r. 
- Pobudzenie zatrudnienia, wzrostu i inwestycji.

- Połączony jednolity rynek cyfrowy.

- Stabilna unia energetyczna z perspektywiczną polityką w kwestii zmiany klimatu.

- Pogłębiony i bardziej sprawiedliwy rynek wewnętrzny oparty na wzmocnionej bazie przemysłowej.

- Pogłębiona i bardziej sprawiedliwa unia gospodarcza i walutowa.

- Zrównoważona i postępowa polityka handlowa w celu wykorzystania możliwości płynących z globalizacji.

- Obszar sprawiedliwości i przestrzegania praw podstawowych, którego podstawą jest wzajemne zaufanie.

- W kierunku nowej polityki w dziedzinie migracji.

- Silniejsza pozycja na arenie międzynarodowej.

- Unia demokratycznych zmian.

W 2018 r. centralnym tematem były negocjacje dotyczące wystąpienia Wielkiej Brytanii z Unii Europejskiej. Poza zdefiniowaniem przyszłych relacji zmiana ta zapoczątkowała szeroką debatę na temat przyszłości całej UE. Osią dyskusji jest opracowana przez Komisję Europejską biała księga w sprawie przyszłości Europy wraz z pakietem dokumentów, w których określono warianty działania w najważniejszych obszarach ${ }^{5}$. Wyniki debaty mają prowadzić do sformułowania konkretnych inicjatyw podczas spotkania szefów państw i rządów 27 krajów UE na specjalnym szczycie 9 maja 2019 r. w Sybinie (Rumunia).

\section{- Geneza dokumentu UE}

Zgodnie z art. 249 ust. 2 Traktatu o funkcjonowaniu Unii Europejskiej (TFUE) Komisja Europejska zobowiązana jest do opublikowania co roku ogólnego sprawozdania z działalności Unii.

\section{- Informacja o stanie prawa obowiązującego w Polsce w materii objętej treścią dokumentu UE}

Ze względu na przeglądowy charakter dokumentu obejmujący wszystkie dziedziny, którymi zajmuje się Komisja Europejska, prezentacja aktów prawnych dotyczących wszystkich omówionych w komunikacie obszarów nie wydaje się celowa.

\footnotetext{
${ }^{5}$ Dokument otwierający debatę dotyczący społecznego wymiaru Europy (COM(2017) 206 final), dokument otwierający debatę dotyczący wykorzystania możliwości płynących z globalizacji (COM(2017) 240 final), dokument otwierający debatę dotyczący pogłębienia unii gospodarczej i walutowej (COM(2017) 291 final), dokument otwierający debatę dotyczący przyszłości europejskiej obronności (COM(2017) 315 final), dokument otwierający debatę dotyczący przyszłości finansów UE (COM(2017) 358 final).
} 


\section{Ocena dokumentu UE}

\section{- Ocena społecznych, gospodarczych i finansowych skutków dokumentu}

Sprawozdanie, jako dokument o charakterze informacyjnym, nie wywołuje bezpośrednich skutków społecznych, gospodarczych ani finansowych dla Polski. Przegląd zrealizowanych działań jest natomiast istotny z perspektywy oceny realizacji założeń ujętych w planie prac na dany rok. W dalszej części opinii przedstawiono krótki komentarz do każdego z działań opisanych w sprawozdaniu, zgodnie z układem przyjętym w tym dokumencie.

- Nowy impuls dla tworzenia miejsc pracy oraz pobudzania wzrostu gospodarczego

W 2018 r. gospodarka europejska osiągnęła dobre wyniki i zgodnie z przewidywaniami ma nadal rosnąć (PKB UE w 2018 r. wzrósł o 2,1\% ${ }^{6}$ ). Po prawie sześciu latach stałego wzrostu państwa członkowskie wykazują również coraz większą konwergencję gospodarczą, która przynosi korzyści obywatelom państw członkowskich. Komisja wywiązała się z obietnicy zwiększenia zatrudnienia, bowiem od 2014 r. utworzono $12,4 \mathrm{mln}$ miejsc pracy, bezrobocie spadło do $6,8 \%$, a zatrudnienie młodzieży wróciło do poziomu z roku 2008. Także inwestycje niemal powróciły do poziomu sprzed kryzysu (od 2015 r. zgodnie z planem inwestycyjnym dla Europy uruchomiono ponad $370 \mathrm{mld}$ euro na inwestycje, tj. znacznie więcej niż zakładano). Oczekuje się, że do 2020 r. Europejski Fundusz na rzecz Inwestycji Strategicznych (EFIS) przyczyni się do powstania ok. 1,4 mln nowych miejsc pracy. Znacznie poprawił się stan finansów publicznych pod względem spadku zadłużenia i deficytu. Według szacunków w 2018 r. deficyt sektora instytucji rządowych i samorządowych w UE spadł do 0,6\% PKB (z 6,2\% w 2009 r.), a relacja długu publicznego do PKB obniżyła się z 88,3\% w 2014 r. do 81,4\%. Inflacja zaś utrzymała się na poziomie $1,7 \%$. Polska dobrze prezentuje się tle tych ogólnych wyników: w 2018 r. PKB zwiększył się o 5,1\%, stopa bezrobocia zmniejszyła się do 3,9\%, a inflacja wyniosła 1,2\%. Pełne porównanie dotyczące finansów publicznych i inwestycji będzie możliwe dopiero po udostępnieniu przez Eurostat oficjalnych danych statystycznych.

Sytuacja banków europejskich nadal się wzmacniała, zmniejszało się ich obciążenie złymi kredytami i były one lepiej przygotowane do radzenia sobie z potencjalnymi wstrząsami gospodarczymi. Mimo tych pozytywnych zmian Komisja podkreśla, że perspektywy gospodarki światowej pogorszyły się w kontekście

6 Przypomnieć jednak należy, że z zimowej prognozy KE z 2019 r. wynika, iż wzrost ten był niższy niż w 2017 r. (2,6\%), ponadto będzie on słabszy w kolejnych dwóch latach (w 2019 r. - 1,5\% i w 2020 - 1,8\%). Dopiero w 2021 r. zwiększy się do 2,2\%. 
napięć handlowych i niepewności geopolitycznej, a ryzyko dla gospodarki europejskiej wzrosło.

Przedstawiając szerzej realizację pierwszego priorytetu „Pobudzenie zatrudnienia, wzrostu i inwestycji”, Komisja zwróciła uwagę na zagadnienia wymienione poniżej.

a) Plan inwestycyjny dla Europy.

b) Polityka gospodarcza i budżetowa, w tym zakończenie procesu tworzenia unii rynków kapitałowych oraz wspieranie niezakłóconej konkurencji na rzecz pobudzania wzrostu gospodarczego i inwestycji.

c) Trwały wzrost gospodarczy w celu tworzenia miejsc pracy i przyczyniania się do ochrony środowiska, w tym przez rozwój „niebieskiej gospodarki”, polityki regionalnej i miejskiej, wykorzystywanie instrumentu „Łącząc Europę” oraz pomoc dla małych i średnich przedsiębiorstw (MŚP) w znalezieniu źródeł finansowania, nowych partnerów i nowych rynków.

d) Wspieranie badań naukowych, innowacji i technologii, w odniesieniu do działalności naukowej i przełomowych innowacji, przestrzeni kosmicznej i europejskiej technologii obronnej.

e) Inwestowanie w ludzi.

f) Działania łączące ludzi przez m.in.: obchody Europejskiego Roku Dziedzictwa Kulturowego, inicjatywę DiscoverEU, Europejski Korpus Solidarności, a także ochronę zdrowia ludzi i wspomaganie gospodarki.

g) Budżet UE zorientowany na rezultaty.

Ad a) Najważniejszym elementem planu inwestycyjnego dla Europy (zainicjowanego w 2015 r.) jest Europejski Fundusz na rzecz Inwestycji Strategicznych. Fundusz ten utworzono przy początkowej zdolności do ponoszenia ryzyka w wysokości 21 mld euro przez UE i Grupę EBI, co miało przyciągać inne źródła finansowania, w szczególności prywatne. Wyniki planu inwestycyjnego przekroczyły oczekiwania i przyjęty cel, ponieważ uruchomiono ponad 370 mld euro zainwestowanych w całej Europie od 2015 r., z czego dwie trzecie pochodzi ze źródeł prywatnych. Dzięki wsparciu z EFIS 856 tys. MŚP skorzystało z lepszego dostępu do finansowania. Szacuje się, że fundusz pomógł już utworzyć ponad 750 tys. miejsc pracy, natomiast do 2020 r. ma powstać 1,4 mln miejsc pracy. Plan inwestycyjny zwiększył poziom PKB UE o 0,6\%, a do 2020 r. wskaźnik ten ma osiągnąć $1,3 \%$. Od chwili uruchomienia plan inwestycyjny pomógł sfinansować dostęp do szerokopasmowego internetu w 15 mln gospodarstw domowych, a także modernizację lub budowę pół miliona mieszkań po przystępnych cenach

„Niebieska gospodarka” obejmuje wszystkie oparte na zasadach, zrównoważone działania gospodarcze związane z oceanami, morzami i obszarami przybrzeżnymi, począwszy od rybołówstwa, przez budownictwo okrętowe i turystykę, aż po energię oceaniczną i niebieską biotechnologię. 
oraz poprawę usług opieki zdrowotnej dla $30 \mathrm{mln}$ Europejczyków. Dzięki niemu 7,4 mln gospodarstw domowych korzysta z energii ze źródeł odnawialnych, a $95 \mathrm{mln}$ pasażerów rocznie korzysta $\mathrm{z}$ udoskonalonej infrastruktury kolejowej i miejskiej. Beneficjentami planu są wszystkie państwa członkowskie, zwłaszcza te, które najdotkliwiej odczuły skutki kryzysu.

Ze względu na swój sukces EFIS ten został udoskonalony w 2018 r., jego okres obowiązywania przedłużono do końca 2020 r., a docelowy poziom inwestycji podniesiono z 315 mld euro do co najmniej 500 mld euro. Nowe przepisy ułatwiają również łączenie finansowania $\mathrm{z}$ funduszu $\mathrm{z}$ finansowaniem $\mathrm{z}$ europejskich funduszy strukturalnych i inwestycyjnych oraz z innymi źródłami finansowania unijnego.

Ad b) Wzrost gospodarczy i tworzenie miejsc pracy wspierane są również przez unijne zasady zarządzania gospodarczego i fiskalnego w ramach tzw. europejskiego semestru na rzecz koordynacji polityki gospodarczej. W marcu 2018 r. Komisja opublikowała sprawozdania dotyczące poszczególnych państw członkowskich $^{8}$, przy czym po raz pierwszy w sprawozdaniach tych położono szczególny nacisk na priorytety europejskiego filaru praw socjalnych. Szczególną uwagę zwrócono na analizę wyzwań związanych z umiejętnościami siły roboczej oraz na sposób funkcjonowania krajowych sieci bezpieczeństwa socjalnego. Ze sprawozdań tych wynika, że państwa członkowskie osiągnęły co najmniej „pewne postępy” w zakresie ponad dwóch trzecich zaleceń dotyczących polityki socjalnej sformułowanych w poprzednim roku.

W maju Komisja przedstawiła państwom członkowskim zalecenia dotyczące polityki gospodarczej. Koncentrowały się one na wzmocnieniu podstaw trwałego wzrostu gospodarczego sprzyjającego włączeniu społecznemu w perspektywie długoterminowej. Komisja wezwała też państwa członkowskie do wykorzystania pozytywnego otoczenia gospodarczego do przeprowadzenia reform strukturalnych, które poprawią warunki prowadzenia działalności gospodarczej i inwestycji, zwłaszcza poprzez reformy rynku produktów i usług, wspieranie innowacji, poprawę dostępu MŚP do finansowania oraz walkę z korupcją. Ponadto Komisja zalecała wzmocnienie odporności gospodarczej na długoterminowe wyzwania, takie jak: zmiany demograficzne, migracja i zmiana klimatu, a także przygotowanie pracowników na przyszłe wyzwania (nowe formy pracy, cyfryzacja). Wskazała również na potrzebę zmniejszania nierówności w dochodach oraz stwarzania możliwości zatrudnienia, w szczególności dla młodych ludzi. Komisja zaproponowała uruchomienie programu wspierania reform (w kwocie 25 mld euro) oraz zapewnienie wsparcia i doradztwa zarówno finansowego, jak i technicznego.

W maju Komisja zakończyła przegląd wydanych w 2015 r. wytycznych w sprawie unijnych reguł fiskalnych. W efekcie tego można stwierdzić, że wytyczne Komisji dotyczące elastyczności pomogły znaleźć właściwą równowagę

$8 \quad$ Z wyjątkiem Grecji, która nadal korzystała z programu pomocy stabilizacyjnej. 
między zapewnieniem rozważnej polityki budżetowej a stabilizacją gospodarki. Szacuje się, że podejście to przyczyniło się do zwiększenia produktu krajowego brutto UE o $0,8 \% \mathrm{w}$ ciągu ostatnich czterech lat i doprowadziło do utworzenia $1,5 \mathrm{mln}$ miejsc pracy.

W maju Komisja podjęła również liczne działania w ramach paktu stabilności i wzrostu. Zaleciła m.in. zamknięcie procedury nadmiernego deficytu w odniesieniu do Francji. W efekcie jedynym państwem członkowskim objętym w $2018 \mathrm{r}$. tą procedurą była Hiszpania9. W opublikowanej w listopadzie rocznej analizie wzrostu gospodarczego KE stwierdziła, że gospodarka europejska będzie nadal rozwijać się w 2019 r.; zauważyła jednak, iż wzrost gospodarki nie przynosi korzyści wszystkim obywatelom i państwom w tym samym stopniu i pozostaje podatny na globalną niestabilność oraz wyzwania średnio- i długoterminowe.

W kwestii kończenia budowy rynków kapitałowych Komisja przypomniała, że w 2018 r.:

- zaproponowała nowe przepisy mające zapewnić MŚP lepszy i tańszy dostęp do finansowania przez rynki publiczne. Propozycje mające przyczynić się do pobudzenia transgranicznego rynku funduszy inwestycyjnych będą wspierać unijny rynek obligacji zabezpieczonych jako źródła finansowania długoterminowego oraz zapewnią inwestorom większą pewność prawa ${ }^{10}$,

- uruchomiony został program paneuropejskiego funduszu funduszy dotyczący kapitału wysokiego ryzyka na podstawie zaproszenia do wyrażenia zainteresowania. Sześć uczestniczących funduszy, przy wsparciu środkami UE w wysokości $410 \mathrm{mln}$ euro, ma zwiększyć inwestycje publiczne i prywatne do 2,1 mld euro. To z kolei powinno przyciągnąć nowe inwestycje o wartości ok. 6,5 mld euro w innowacyjne przedsiębiorstwa typu start-up i scale-up w całej Europie, podwajając wielkość kapitału wysokiego ryzyka, który jest obecnie dostępny w Europie, - przyjęła nowe przepisy w celu pobudzenia inwestycji ubezpieczycieli w prostą, przejrzystą i standardową sekurytyzację,

- Parlament i Rada osiągnęły porozumienie polityczne w sprawie podstawowych elementów ogólnoeuropejskiego indywidualnego produktu emerytalnego, czyli dobrowolnego systemu oszczędzania na emeryturę dla obywateli, w tym w kontekście transgranicznym.

W kwestii wspierania niezakłóconej konkurencji na rzecz pobudzania wzrostu gospodarczego i inwestycji Komisja przypomniała, że w roku 2018:

- egzekwowała przepisy dotyczące konkurencji z korzyścią dla gospodarstw domowych i przedsiębiorstw, zapewniając równe warunki działania oraz szerszy

9 Dla porównania w 2011 r. procedura ta obejmowała aż 24 państwa.

10 Komisja przypomina, że obecnie brak jest pewności prawa co do tego, które prawo krajowe ma zastosowanie przy ustalaniu, kto posiada wierzytelność po dokonaniu jej przelewu w przypadku sprawy transgranicznej. Proponowane nowe zasady precyzują, na mocy którego prawa rozstrzyga się takie spory. 
wybór i lepsze ceny dla konsumentów. Przyjęła też nowe przepisy i narzędzia umożliwiające skuteczniejsze egzekwowanie przepisów antymonopolowych, - podjęła 393 decyzje w sprawie połączeń, 10 decyzji antymonopolowych, cztery decyzje dotyczące karteli oraz 219 decyzji w sprawie pomocy państwa, co przyniosło istotne korzyści dla konsumentów w UE oraz wspierało wzrost gospodarczy. W sumie nałożyła grzywny w wysokości 6,3 mld euro na przedsiębiorstwa naruszające unijne reguły konkurencji oraz zobowiązała zainteresowane państwa członkowskie do odzyskania od przedsiębiorstw będących beneficjentami pomocy kwoty ok. 1 mld euro pomocy niezgodnej z prawem i z rynkiem wewnętrznym. Aż 91\% spraw dotyczących pomocy państwa zostało objętych uproszczonymi zasadami w ramach ogólnego rozporządzenia w sprawie wyłączeń blokowych, co oznacza, że pomoc państwa może zostać przyznana na szczeblu lokalnym, regionalnym i krajowym bez udziału Komisji.

Ad c) W ramach szerzej zakrojonych wysiłków na rzecz poprawy stabilności europejskiej gospodarki Komisja przyjęła nową strategię dotyczącą tworzyw sztucznych, której celem jest przekształcenie sposobu projektowania, produkcji, stosowania i recyklingu tworzyw sztucznych. Zgodnie z nowymi planami do $2030 \mathrm{r}$. wszystkie opakowania z tworzyw sztucznych na rynku UE będą musiały nadawać się do recyklingu lub ponownego wykorzystania, zmniejszy się zużycie tworzyw sztucznych jednorazowego użytku, a ponadto zostaną wprowadzone ograniczenia dotyczące celowego stosowania mikrodrobin plastiku. Komisja przedstawiła też wniosek ustawodawczy mający na celu rozwiązanie problemu odpadów morskich u źródła poprzez skoncentrowanie działań na dziesięciu produktach z tworzyw sztucznych, które najczęściej trafiają do oceanów, a także na zagubionych i porzuconych narzędziach połowowych. Z kolei Parlament Europejski i Rada osiągnęły tymczasowe porozumienie polityczne w sprawie nowej dyrektywy UE o produktach plastikowych jednorazowego użytku, która stanowi najbardziej ambitny instrument prawny na szczeblu światowym dotyczący odpadów morskich.

Zgodnie z nowymi przepisami dotyczącymi odpadów UE ma stać się światowym liderem w gospodarowaniu odpadami i recyklingu. Państwa członkowskie będą musiały poddawać recyklingowi co najmniej 55\% odpadów komunalnych do 2025 r., $60 \%$ do 2030 r. i 65\% do 2035 r. Inne zatwierdzone środki obejmują ograniczenie do 10\% ilości składowanych odpadów do 2035 r., obowiązkowe selektywne zbieranie bioodpadów, a także surowsze systemy, według których producenci płacą za zbieranie kluczowych odpadów nadających się do recyklingu. W wyniku ogólnounijnej kampanii składania zobowiązań w ramach europejskiej strategii dotyczącej tworzyw sztucznych Komisja przedstawiła wstępną ocenę, zgodnie z którą do 2025 r. możliwe jest osiągnięcie co najmniej $10 \mathrm{mln}$ ton tworzyw sztucznych pochodzących z recyklingu, jeżeli zobowiązania te zostaną w pełni zrealizowane.

Kontynuowano również prace nad poprawą zrównoważonej gospodarki wodnej o obiegu zamkniętym, a także nad zwiększeniem bezpieczeństwa wody 
pitnej dla wszystkich Europejczyków. Komisja zaproponowała przegląd dyrektywy w sprawie wody pitnej w celu podniesienia jej norm, poprawy dostępu do wody dla wszystkich oraz ułatwienia konsumentom dostępu do wiarygodnych informacji na temat jej dostaw. Była to m.in. odpowiedź na pierwszą udaną europejską inicjatywę obywatelską „Right2Water”, którą poparło 1,6 mln osób. Jej celem jest zachęcenie konsumentów do korzystania $\mathrm{z}$ wody wodociągowej zamiast butelkowanej, a tym samym do oszczędności pieniędzy, ograniczenia ilości odpadów z tworzyw sztucznych oraz obniżenia emisji gazów cieplarnianych. Komisja przedstawiła również propozycje dotyczące zrównoważonego finansowania, mające na celu zapewnienie, by sektor finansowy odgrywał większą rolę $\mathrm{w}$ przechodzeniu na zieloną gospodarkę.

W 2018 r. Komisja opublikowała pierwsze sprawozdanie roczne dotyczące szybko rosnącego sektora niebieskiej gospodarki, którego wielkość na całym świecie ma się podwoić do $2030 \mathrm{r}$. W sprawozdaniu podkreślono, że niebieska gospodarka generuje ponad 560 mld euro obrotów, zatrudnia ponad 3,5 mln osób i jest szybko rozwijającym się sektorem w wielu krajach ${ }^{11}$.

Unia w dalszym ciągu inwestowała $\mathrm{w}$ strategie polityczne mające na celu wzmocnienie konkurencyjności i tworzenia miejsc pracy, wspieranie włączenia społecznego oraz MŚP w kontekście regionalnym i lokalnym. Wdrożono liczne inicjatywy i strategie celem pobudzenia wzrostu gospodarczego i innowacyjności, w tym nowy zestaw działań mających pomagać regionom Europy inwestować w niszowe dziedziny, w których są one konkurencyjne (,inteligentna specjalizacja"). Działania te obejmują dalsze wspieranie inicjatywy dotyczących regionów słabiej rozwiniętych oraz realizację nowej inicjatywy ukierunkowanej na regiony przechodzące transformację przemysłową. W tym zakresie zrealizowano działania pilotażowe $\mathrm{w}$ dziesięciu regionach, które otrzymały porady ekspertów i wsparcie finansowe z EFRR i Europejskiego Obserwatorium Klastrów i Zmian w Przemyśle. Komisja wybrała również pięć programów polityki spójności, które mają uczestniczyć w nowym działaniu pilotażowym dotyczącym poprawy zdolności administracyjnych. W ramach instrumentu „Łącząc Europę” wybrano 35 projektów w dziedzinie bezpiecznej, czystej i inteligentnej mobilności, które otrzymają dotacje w wysokości $405 \mathrm{mln}$ euro. Udzielono też wsparcia projektom mającym na celu rozwój jednolitej europejskiej przestrzeni powietrznej i europejskiego lotnictwa. Kwota w wysokości ok. 9,5 mln euro w ramach wspólnego przedsięwzięcia w celu opracowania europejskiego systemu zarządzania ruchem lotniczym nowej generacji (SESAR) zostanie przeznaczona na sfinansowanie

11 Jedna piąta pracowników zatrudnionych w tym sektorze pracuje w Hiszpanii, a w dalszej kolejności - we Włoszech, w Zjednoczonym Królestwie i Grecji. Łącznie te cztery państwa członkowskie odpowiadają za ponad połowę miejsc pracy związanych z niebieską gospodarką. 
prób dotyczących dronów U-space, ze szczególnym uwzględnieniem bezpiecznego włączenia dronów do systemu lotnictwa.

Co roku UE wspiera małe przedsiębiorstwa przez zapewnienie różnych rodzajów finansowania i usług doradczych. Poczynione zostały znaczne postępy w zakresie poprawy dostępu tych przedsiębiorstw do finansowania. W ramach programu COSME zapewniono finansowanie w wysokości ponad 20,3 mld euro na rzecz ok. 381 tys. małych przedsiębiorstw.

Ad d) W odniesieniu do kwestii związanych ze wspieraniem badań naukowych, innowacji i technologii oraz przestrzeni kosmicznej, a także europejskiej technologii obronnej Komisja kontynuowała program „Horyzont 2020”, w którym ogłoszono zaproszenia do składania wniosków oraz inne działania o łącznej wartości 10 mld euro (w tym: produkcja akumulatorów nowej generacji, gospodarka o obiegu zamkniętym, zbadanie pierwotnych przyczyn nielegalnej migracji). Ponadto ustanowiono fundusz w wysokości $100 \mathrm{mln}$ euro skierowany do innowatorów i przedsiębiorstw z UE, którzy mogą doprowadzić do znacznego i trwałego ograniczenia emisji gazów cieplarnianych.

Z innych ważnych działań należy wymienić:

- uruchomienie europejskiej chmury dla otwartej nauki, tzn. wirtualnej przestrzeni do przechowywania, udostępniania i ponownego wykorzystywania danych w różnych dyscyplinach, z której korzysta ok. 1,7 mln naukowców i $70 \mathrm{mln}$ specjalistów,

- rozwijanie infrastruktury kosmicznej ${ }^{12}$ na bazie „Strategii kosmicznej dla Europy" - uruchomienie siódmego satelity programu Copernicus przyczyniło się do poprawy zdolności monitorowania oceanów, gruntów i atmosfery; usługi w zakresie dostępu do danych i informacji w ramach tego programu umożliwiają innowacyjnym przedsiębiorstwom typu start-up i innym użytkownikom łatwy dostęp do danych oraz ich łatwe przetwarzanie i pobieranie, bez konieczności inwestowania w kosztowne urządzenia do przechowywania i przetwarzania danych,

- poprawę wydajności systemu Galileo ${ }^{13}$ dzięki czterem nowym satelitom umieszczonym na orbicie - sygnały z satelitów wykorzystuje się na potrzeby zarządzania ruchem drogowym i kolejowym, nawigacji statków powietrznych, bankowości, rolnictwa, w pracach nad samochodami autonomicznymi itp. ${ }^{14}$,

12 W czerwcu 2018 r. Komisja zaproponowała program kosmiczny o wartości 16 mld euro.

13 Galileo, unijny program nawigacji satelitarnej, zapewnia precyzyjne usługi pozycjonowania, nawigacji i pomiaru czasu oraz może być wykorzystywany w najnowszej generacji smartfonów, co skutkuje większą dokładnością niż poprzednie systemy oparte wyłącznie na GPS.

14 Komisja przyjęła też nowe środki mające pomóc w lepszej lokalizacji poprzez sygnały Galileo osób znajdujących się w sytuacjach nadzwyczajnych, dzięki czemu działania ratownicze będą skuteczniejsze. Zgodnie z nowymi przepisami wszystkie smartfony 
- zainwestowanie $40 \mathrm{mln}$ euro $\mathrm{w}$ finansowanie wspólnych badań w zakresie innowacyjnych technologii i produktów obronnych w ramach działania przygotowawczego w zakresie badań nad obronnością. Przyjęto nowy „Europejski program rozwoju przemysłu obronnego", aby zapewnić wsparcie finansowe w fazie rozwojowej nowych produktów i technologii w obszarach wybranych na szczeblu europejskim. Przewiduje on na lata 2019 i 2020 budżet w wysokości $500 \mathrm{mln}$ euro na współfinansowanie realizowanych na zasadzie współpracy projektów dotyczących rozwoju zdolności obronnych.

Ad e) W obszarze związanym $\mathrm{z}$ inwestowaniem w ludzi Komisja wskazała między innymi, że:

- przyjęto zalecenie w sprawie ram jakości i skuteczności przygotowania zawodowego, zawierające kryteria wspierania dobrych warunków uczenia się i pracy dla praktykantów w całej UE,

- uproszczono i zmodernizowano życiorys Europass CV, który pomoże obywatelom prezentować swoje umiejętności i kwalifikacje w sposób bardziej widoczny i zrozumiały na jednolitym rynku. Umożliwi to również decydentom lepsze przewidywanie potrzeb i tendencji na rynku pracy,

- wydano zalecenia dla 20 państw członkowskich poświęcone reformom systemów kształcenia i szkolenia,

- Rada przyjęła zalecenia w sprawie kompetencji kluczowych w uczeniu się przez całe życie oraz przyjęła środki dotyczące automatycznego wzajemnego uznawania kwalifikacji i efektów uczenia się osiągniętych w okresach nauki za granicą, - realizowany jest plan działania na rzecz poprawy umiejętności cyfrowych obywateli UE i wykorzystania nowych technologii w nauczaniu i uczeniu się.

$\boldsymbol{A d} \mathbf{f})$ Działania łączące ludzi realizowano m.in. przez: obchody Europejskiego Roku Dziedzictwa Kulturowego, inicjatywę DiscoverEU, Europejski Korpus Solidarności, Program Erasmus+. Komisja zaproponowała podwojenie finansowania programu Erasmus do kwoty 30 mld euro w budżecie na lata 2021-2027, a także znaczne rozszerzenie programu DiscoverEU. Europejski Korpus Solidarności został wzmocniony dzięki przyjęciu odrębnej podstawy prawnej oraz przyznaniu środków na kolejne trzy lata ${ }^{15}$. Komisja zaproponowała też nowy program na rzecz tego korpusu na okres po 2020 r., z budżetem w wysokości 1,26 mld euro $^{16}$.

Komisja działała także w obszarze podnoszenia zdrowotności. Ministrowie zdrowia przyjęli zaproponowane przez Komisję zalecenie w sprawie wzmoc-

sprzedawane w UE będą mogły przesyłać służbom ratunkowym dokładną lokalizację osoby dzwoniącej na numer alarmowy 112.

15 Do końca grudnia zarejestrowało się prawie 100 tys. młodych ludzi, a 11 tys. osób uczestniczyło w działaniach solidarnościowych w całej Europie.

16 Umożliwi to co najmniej 350 tys. młodych Europejczyków wspieranie społeczności potrzebujących pomocy poprzez wolontariat, a także uczestniczenie w stażach i praktykach zawodowych w latach 2021-2027. 
nienia współpracy w walce $\mathrm{z}$ chorobami, którym można zapobiegać za pomocą szczepionek. Zalecenie to koncentruje się na: przeciwdziałaniu niechęci do szczepień i poprawie wyszczepialności; zrównoważonej polityce szczepień w UE oraz koordynacji na szczeblu UE i przyczynianiu się do zdrowia na świecie. W opublikowanym w listopadzie 2018 r. przez Komisję i OECD sprawozdaniu „Zdrowie i opieka zdrowotna w zarysie: Europa 2018” wezwano do poprawy zdrowia psychicznego i zapobiegania chorobom psychicznym, które mają nie tylko konsekwencje społeczne, ale jednocześnie kosztują ponad 4\% PKB UE. W sprawozdaniu wykazano również, że stały wzrost średniego dalszego trwania życia uległ spowolnieniu oraz że utrzymują się znaczne różnice między państwami i w ich obrębie, przy czym zwłaszcza osoby o niskim poziomie wykształcenia znajdują się w niekorzystnej sytuacji. Wezwano także do zajęcia się czynnikami ryzyka (takimi jak: palenie tytoniu, alkohol czy otyłość), do przeciwdziałania przedwczesnym zgonom, zapewnienia powszechnego dostępu do opieki zdrowotnej oraz wzmocnienia odporności systemów opieki zdrowotnej ${ }^{17}$.

Komisja Europejska w ścisłej współpracy z Organizacją Współpracy Gospodarczej i Rozwoju oraz Europejskim Obserwatorium Polityki i Systemów Opieki Zdrowotnej przygotowała dwuletni cykl „Stan zdrowia w UE”. Przedstawiła też wniosek dotyczący ograniczenia narażenia pracowników na pięć kolejnych rakotwórczych substancji chemicznych, którego celem jest wzmocnienie ochrony ponad $1 \mathrm{mln}$ pracowników w Europie. Przyjęte zostały ograniczenia stosowania trzech neonikotynoidów w środkach ochrony roślin w celu ochrony pszczół i owadów zapylających oraz inicjatywa na rzecz rozwiązania problemu spadku liczebności dzikich owadów zapylających.

Ad g) Budżet UE na 2018 r. koncentrował się na realizacji przyjętych priorytetów poprzez wspieranie tworzenia miejsc pracy, zwłaszcza dla ludzi młodych, oraz pobudzanie wzrostu gospodarczego i inwestycji strategicznych. Wspierał również działania mające na celu sprostanie wyzwaniom związanym z migracją i bezpieczeństwem, zarówno w UE, jak i poza jej granicami.

Prawie połowę przyznanych środków (77,5 mld euro) przeznaczono na wzmocnienie europejskiej gospodarki, tworzenie miejsc pracy i poprawę globalnej konkurencyjności przedsiębiorstw, badaczy i uniwersytetów. Finansowanie ze środków UE wspierało rolnictwo i obszary wiejskie (wspólna polityka rolna), regiony [Europejski Fundusz Rozwoju Regionalnego, Europejski Fundusz Społeczny (EFS), Fundusz Spójności], badania naukowe i innowacje („Horyzont 2020”), małe i średnie przedsiębiorstwa (program COSME), kształcenie, szkolenie i młodzież (Erasmus+), transport i infrastrukturę cyfrową (instrument „Łącząc Europę”).

17 Wraz z publikacją sprawozdania Komisja rozpoczęła drugi cykl inicjatywy „Stan zdrowia w UE”, w której analizuje się i przekazuje dane porównawcze dotyczące opieki zdrowotnej oraz wspiera organy ds. zdrowia w kształtowaniu polityki na podstawie dowodów. 
W ramach inicjatywy na rzecz zatrudnienia ludzi młodych $350 \mathrm{mln}$ euro przeznaczono na zapewnienie młodym ludziom wsparcia i lepszych możliwości znalezienia pracy. W ramach zaś EFIS dodatkowe 2 mld euro przeznaczono na dalszą skuteczną mobilizację prywatnych inwestycji w strategiczne projekty europejskie. Kwota w wysokości 59,2 mld euro przyczyniła się do popierania zrównoważonego wzrostu poprzez wsparcie dla rolników i rybołówstwa, ograniczanie zmiany klimatu oraz dbanie o różnorodność biologiczną.

Wniosek dotyczący długoterminowego budżetu UE na lata 2021-2027 został przedstawiony przez KE w maju 2018 r. Uzupełnia go zestaw wniosków dotyczących programów sektorowych i funduszy. Komisja zaproponowała, aby wszystkie unijne programy finansowania w ramach budżetu na lata 2021-2027 opierały się na tym samym modelu. Liczne programy finansowania oferowane obecnie przez UE byłyby objęte jednym programem InvestEU. Podobnie jak w przypadku planu inwestycyjnego program InvestEU obejmowałby fundusz, centrum doradztwa i portal inwestycyjny. Fundusz InvestEU dysponowałby zabezpieczeniem w wysokości 38 mld euro z budżetu UE na wspieranie projektów o dużym znaczeniu strategicznym w całej UE w takich sektorach, jak: zrównoważona infrastruktura; badania naukowe, innowacje i cyfryzacja; małe i średnie przedsiębiorstwa oraz inwestycje społeczne i umiejętności. Szacuje się, że w ciągu siedmiu lat fundusz pozwoli uruchomić ponad 650 mld euro dodatkowych inwestycji.

W nowym programie „Horyzont Europa”, z budżetem w kwocie 100 mld euro na badania i innowacje w latach 2021-2027, Komisja zaplanowała zwiększenie inwestycji celem utrzymania wiodącej pozycji Europy w zakresie badań i innowacji na świecie. Komisja zaproponowała, aby UE zainwestowała 16 mld euro w unijny program kosmiczny oraz 13 mld euro na Europejski Fundusz Obronny.

Utrzymane będzie silne wsparcie dla rolnictwa i obszarów wiejskich dzięki przeznaczeniu 365 mld euro na wspólną politykę rolną (WPR) w latach 20212027. Wnioski dotyczące WPR koncentrują się na uproszczeniu i modernizacji polityki, tak aby odpowiadała ona na wyzwania, które pojawią się w przyszłości. Oprócz tradycyjnych celów w zakresie dochodów gospodarstw, bezpieczeństwa żywnościowego i ochrony środowiska, plany dotyczą również nowych potrzeb społecznych, takich jak bezpieczna, bogata w składniki odżywcze i zrównoważona żywność, zwalczanie marnotrawienia żywności i dobrostan zwierząt.

Komisja zaproponowała również utworzenie nowego Europejskiego Funduszu Morskiego i Rybackiego z kwotą 6,14 mld euro w celu zwiększenia wsparcia dla gospodarki morskiej, przy jednoczesnym dążeniu do uproszczenia i większej koncentracji na wynikach. Fundusz ma umożliwić inwestowanie w nowe rynki, technologie i usługi morskie, takie jak energia oceaniczna i biotechnologia morska. Społeczności nadbrzeżne otrzymają większe wsparcie, a fundusz będzie nadal udzielał wsparcia europejskiemu sektorowi rybołówstwa, ze szczególnym naciskiem na wspieranie tradycyjnego łodziowego rybołówstwa przybrzeżnego. 
Na rzecz polityki spójności Komisja zaproponowała budżet w wysokości 373 mld euro, koncentrując się na modernizacji gospodarki europejskiej, czynieniu jej inteligentniejszą, bardziej ekologiczną i bardziej połączoną, a także na przechodzeniu na gospodarkę niskoemisyjną. Przewidziano również uproszczenie przepisów, tak aby jeden zbiór przepisów obejmował siedem funduszy oraz uelastycznienie procedur.

Komisja zaproponowała wzmocnienie społecznego wymiaru Unii poprzez ulepszony Europejski Fundusz Społeczny. Nowy EFS+ dysponowałby budżetem w kwocie 101,2 mld euro. Dzięki temu miałby większy wpływ na inwestycje społeczne. Połączenie EFS+, Erasmusa i Europejskiego Korpusu Solidarności mogłoby ponad dwukrotnie zwiększyć środki przeznaczone na wspieranie młodych ludzi w porównaniu z obecnymi ramami finansowymi. Europejski Fundusz Dostosowania do Globalizacji zostałby zmieniony, jego zakres - rozszerzony (środki wzrosłyby do $225 \mathrm{mln}$ euro rocznie w porównaniu ze $170 \mathrm{mln}$ euro rocznie obecnie).

- Połączony jednolity rynek cyfrowy

Maksymalizacja wzrostu gospodarczego i korzyści społecznych przez europejską gospodarkę cyfrową jest jednym z elementów „Strategii jednolitego rynku cyfrowego dla Europy" ${ }^{18}$. Dokończenie jego budowy należy do priorytetów Komisji Europejskiej, bowiem wyeliminowanie barier w rozwoju rynku cyfrowego mogłoby zwiększyć PKB państw członkowskich UE o 415 mld euro.

W 2018 r. osiągnięto porozumienie w sprawie 23 inicjatyw ustawodawczych, a siedem pozostaje przedmiotem negocjacji. Weszły w życie nowe regulacje dotyczące m.in. handlu elektronicznego, bezpieczeństwa sieci i systemów informatycznych, prawa autorskiego oraz danych osobowych i prywatności w internecie. W grudniu 2018 r. wszedł w życie nowy europejski kodeks łączności elektronicznej zawierający zaktualizowane ramy regulacyjne dotyczące łączności elektronicznej i ułatwiający inwestycje w sieci o dużej przepustowości. Najważniejsze nowe inicjatywy (ustawodawcze i nieustawodawcze), będące przedmiotem prac Komisji w ubiegłym roku, dotyczyły cyberbezpieczeństwa, zwalczania dezinformacji w internecie, dostępności danych sektora publicznego, sztucznej inteligencji, e-zdrowia, domen „eu” najwyższego poziomu oraz innowacji technologicznych w sektorze finansowym.

Ważnym aspektem działań Komisji Europejskiej w obszarze jednolitego rynku cyfrowego jest przeciwdziałanie antykonkurencyjnym zachowaniom w dziedzinie cyfrowej. W 2018 r. w celu zapewniania zasad uczciwej konkurencji w gospodarce cyfrowej Komisja nałożyła wysokie kary finansowe na dwie amerykańskie spółki: Google (w wysokości 4,43 mld euro) i Qualcomm (997 mln euro).

$18 \operatorname{COM}(2015) 192$ final. 
Dążąc do dalszego wzmocnienia jednolitego rynku cyfrowego i utrzymania pozycji UE w obszarze transformacji cyfrowej, Komisja zaproponowała w ramach kolejnej perspektywy budżetowej (2021-2027) nowy program „Cyfrowa Europa” z budżetem w wysokości 9,2 mld euro. Środki te mają zostać przeznaczone na wsparcie pięciu obszarów: obliczeń wielkiej skali, sztucznej inteligencji, cyberbezpieczeństwa, rozwijania umiejętności cyfrowych oraz transformacji cyfrowej i interoperacyjności.

- Stabilna unia energetyczna z przyszłościową polityką w kwestii zmiany klimatu

- Polityka klimatyczna

Ubiegły rok był bogaty w wydarzenia istotne z punktu widzenia polityki klimatycznej. Najnowsze działania UE w tej dziedzinie w dużej mierze opierają się na rekomendacjach Międzyrządowego Zespołu ds. Zmian Klimatu (IPCC) wzywających do pilnego przyspieszenia globalnych wysiłków na rzecz ochrony klimatu.

W grudniu 2018 r. w Katowicach odbyła się Konferencja Stron Konwencji Klimatycznej (COP24). Aktywna postawa UE przyczyniła się do sukcesu tej konferencji. W trakcie negocjacji Unia podejmowała liczne inicjatywy na rzecz osiągnięcia kompromisu, który zadowalałby wszystkie strony porozumienia, zarówno kraje rozwijające się, jak i rozwinięte. W efekcie uzgodniono zestaw zasad i decyzji umożliwiających praktyczne funkcjonowanie Porozumienia paryskiego. Oznacza to, że w długim czasie ambitna polityka klimatyczna będzie domeną nie tylko UE, ale też będzie realizowana $\mathrm{w}$ innych kluczowych gospodarkach świata.

W ramach Porozumienia paryskiego UE zobowiązała się do redukcji do 2030 r. emisji gazów cieplarnianych o co najmniej 40\% w stosunku do poziomu z 1990 r. Zrodziło to potrzebę wdrożenia środków nakierowanych na szybsze i głębsze redukowanie emisji. W 2018 r. działania te zostały sfinalizowane bądź weszły w końcową fazę uzgodnień. Obejmują one m.in. reformę systemu handlu uprawnieniami do emisji na okres po $2020 \mathrm{r}$. oraz przygotowanie krajowych planów klimatyczno-energetycznych zgodnie z rozporządzeniem w sprawie zarządzania unią energetyczną. Równolegle podjęte zostały dodatkowe kroki ustawodawcze m.in. w zakresie efektywności energetycznej i odnawialnych źródeł energii, transportu drogowego oraz wdrażania zasad gospodarki o obiegu zamkniętym.

W listopadzie 2018 r. Komisja Europejska przedstawiła projekt nowej długoterminowej polityki klimatycznej UE pt. „Czysta planeta dla wszystkich”19. Projekt zakłada „społecznie sprawiedliwą transformację ekonomiczną i społeczną", której celem jest osiągnięcie pełnej dekarbonizacji, czyli całkowitej redukcji emisji $\mathrm{CO}_{2}$ netto, do 2050 r. Będzie ona wymagać wspólnych działań, m.in.:

$19 \operatorname{COM}(2018) 773$ final. 
w zakresie podnoszenia efektywności energetycznej, powszechnego wdrożenia odnawialnych źródeł energii i postępu technologicznego w przemyśle. Propozycja Komisji oznacza nie tylko odejście od węgla jako nośnika energii, ale też radykalne ograniczenie wykorzystania pozostałych paliw kopalnych - ropy i gazu. Realizując tę strategię, Komisja zaproponowała osiem scenariuszy zmian. Różnią się one zakładanymi poziomami zapotrzebowania na energię, tempem wprowadzania takich rozwiązań technologicznych, jak: magazynowanie energii, wykorzystanie wodoru jako paliwa, pochłaniania $\mathrm{CO}_{2} \mathrm{w}$ rolnictwie i leśnictwie oraz tempem zmian w postawach konsumenckich.

Nowa europejska strategia klimatyczna niesie ze sobą poważne konsekwencje dla Polski. Całkowite zaprzestanie wykorzystywania węgla do produkcji energii do 2050 r. stoi w sprzeczności z projektem „Polityki energetycznej Polski” przygotowywanym aktualnie przez Ministerstwo Energii. Może to prowadzić do konfliktów z Brukselą, a także utrudnić inwestycje w nowe bloki węglowe (np. budowę elektrowni Ostrołęka). Dlatego w dyskusjach nad propozycjami Komisji warto podkreślać, że przedstawiony projekt strategii uwzględnia jedynie wartości uśrednione na poziomie całej UE. Tymczasem ze względu na różne punkty startowe nie wszystkie państwa członkowskie będą w stanie osiągnąć neutralność klimatyczną w jednym momencie. Przed zakończeniem prac nad strategią należałoby dokładnie przeanalizować indywidualny potencjał redukcyjny każdego z państw członkowskich, biorąc pod uwagę jego uwarunkowania, w tym ekonomiczne i społeczne koszty transformacji.

W projekcie nowej unijnej strategii klimatycznej podkreśla się, że niezależnie od wybranego scenariusza zmian europejskie społeczeństwo do 2050 r. przejdzie głęboką transformację. Dotyczy to szczególnie regionów uzależnionych ekonomicznie od wysokoemisyjnych sektorów, takich jak górnictwo czy przemysł ciężki. Komisja Europejska dostrzega, że regionom takim będzie potrzebne wsparcie. Dla Polski może to być argument, aby uzyskać dodatkowe środki na finansowanie polityki społecznej i gospodarczej na obszarach górniczych. Ma to szczególne znaczenie w czasie prac nad ustaleniami dotyczącymi kolejnych wieloletnich ram finansowych, zwłaszcza wobec zapowiadanego ograniczenia Funduszu Spójności.

\section{- Unia energetyczna}

Rok 2018 był okresem intensywnych prac nad uzgadnianiem i przyjmowaniem ram prawnych wynikających z przedstawionych w 2016 r. i 2017 r. pakietów „Czysta energia dla wszystkich Europejczyków” (tzw. pakiet zimowy) oraz „Europa w ruchu” (tzw. pakiet mobilności). W ubiegłym roku weszły już w życie nowe przepisy w zakresie efektywności energetycznej w sektorze budynków oraz rozporządzenie dotyczące zarządzania unią energetyczną. W grudniu 2018 r. uzgodniono także nowe przepisy dotyczące lepszego funkcjonowania rynku energii elektrycznej w UE, osiągnięto również porozumienia w sprawie środków 
poprawiających ochronę obywateli europejskich przed krytycznymi niedoborami energii elektrycznej oraz wzmacniających rolę Agencji ds. Współpracy Organów Regulacji Energetyki. W pozostałych projektach legislacyjnych pakietu zimowego uzgodnienia są na tyle zaawansowane, że nowe przepisy powinny zostać przyjęte w pierwszej połowie $2019 \mathrm{r}$.

Kontynuowane były, z pozytywnym skutkiem, działania na rzecz rozwoju infrastruktury energetycznej. Litwa, Łotwa, Estonia i Polska ostatecznie zawarły porozumienie dotyczące synchronizacji sieci elektroenergetycznej państw bałtyckich z europejską siecią kontynentalną do 2025 r., zaś Francja, Hiszpania i Portugalia uzgodniły działania mające na celu wzmocnienie integracji Półwyspu Iberyjskiego $\mathrm{z}$ europejskim rynkiem energii. Osiągnięto porozumienia w zakresie międzysystemowych połączeń gazowych między Bułgarią i Serbią, Bułgarią i Grecją czy Polską i Litwą. Dzięki zakończeniu prac uzgodnieniowych między Polską a Danią już wkrótce ruszą prace nad budową gazociągu „Baltic Pipe”.

Istotnym elementem unijnej polityki klimatyczno-energetycznej jest niskoemisyjny transport. Komisja przedstawiła propozycję pierwszych $w$ historii norm emisji $\mathrm{CO}_{2}$ dla pojazdów ciężkich - w $2025 \mathrm{r}$. średni poziom emisji $\mathrm{CO}_{2} \mathrm{z}$ nowych samochodów ciężarowych ma być o 15\% niższy niż w 2019 r. Parlament Europejski i Rada osiągnęly też porozumienie polityczne w sprawie dekarbonizacji i modernizacji sektora pojazdów lekkich na okres po 2020 r. W 2030 r. emisje z nowych samochodów osobowych będą musiały być o $37,5 \%$ niższe, a z nowych samochodów dostawczych - o 31\% niższe niż w 2021 r. We wrześniu 2018 r. zaczął obowiązywać nowy system badań emisji nowych samochodów osobowych badanie emisji w rzeczywistych warunkach jazdy zapewni wiarygodne pomiary i dostarczy konsumentom lepszą informację o wydajności i emisyjności pojazdów. Komisja zatwierdziła również środki wspierające przejście na transport niskoemisyjny, m.in. w zakresie wsparcia zakupu pojazdów niskoemisyjnych, budowy infrastruktury służącej do ładowania pojazdów czy modernizacji starszych autobusów z silnikiem wysokoprężnym.

Oceniając aktywność Komisji w obszarze unii energetycznej, należy generalnie wyrazić pozytywną ocenę. W procesie uzgadniania ostatecznego kształtu ram prawnych "pakietu zimowego" udało się osiągnąć rozsądne kompromisy, które uwzględniły specyfikę poszczególnych rynków energii. Dzięki temu część rozwiązań prawnych już weszła w życie, a pozostałe powinny być uchwalone w pierwszej połowie $2019 \mathrm{r}$. Na pozytywną ocenę zasługują też działania UE na rzecz rozbudowy infrastruktury energetycznej, co np. w przypadku Polski zaowocowało podpisaniem (i skierowaniem do ratyfikacji) ostatecznej umowy w sprawie realizacji gazociągu „Baltic Pipe” czy zawarciem porozumienia w sprawie synchronizacji sieci energetycznej krajów bałtyckich z Polską.

Pewne obawy mogą natomiast budzić niektóre propozycje w zakresie mobilności niskoemisyjnej. Przedstawione propozycje zaostrzonych norm emisji z samochodów osobowych i dostawczych mogą postawić europejski przemysł moto- 
ryzacyjny w trudnej sytuacji. Nowych norm nie będzie w stanie spełnić większość tradycyjnych silników spalinowych, ale także część pojazdów z napędem hybrydowym. Jednocześnie zastąpienie tych pojazdów produkcją np. samochodów elektrycznych może napotkać barierę popytu (cena, dostępność surowców do produkcji baterii, infrastruktura ładowania). Alternatywą pozostaje wzrost cen pojazdów tradycyjnych, m.in. z powodu kar płaconych przez producentów za przekroczenie średniej emisyjności floty pojazdów danego producenta.

- Pogłębiony i bardziej sprawiedliwy rynek wewnętrzny oparty na wzmocnionej bazie przemysłowej

W 2018 r. miało miejsce 25-lecie ustanowienia jednolitego rynku, który jest jednym z największych osiągnięć integracji europejskiej. Jego celem jest umożliwienie swobodnego przepływu towarów, usług, kapitału i osób, dzięki czemu przedsiębiorcy i pracownicy mają większe szanse rozwoju, a konsumenci większy wybór dóbr i usług oraz niższe ceny. Możliwości te nadal nie są w pełni wykorzystywane, ponieważ przepisy dotyczące jednolitego rynku nie są wystarczająco szeroko znane, nie zostały wdrożone bądź też ich stosowanie utrudniają różnego rodzaju nieuzasadnione przeszkody. Biorąc to pod uwagę, w listopadzie 2018 r. Komisja opublikowała komunikat ${ }^{20}$, w którym wskazała na trzy kluczowe obszary, gdzie konieczne są dalsze działania w celu pogłębienia i wzmocnienia jednolitego rynku. Obejmują one: 1) wezwanie państw członkowskich do odpowiedniego wdrażania, stosowania i egzekwowania przepisów unijnych oraz powstrzymania się od tworzenia nowych barier; 2) wezwanie Parlamentu Europejskiego i Rady do przyjęcia zaproponowanych przez Komisję przepisów, mających zapewnić prawidłowe funkcjonowanie jednolitego rynku; 3) wskazanie na znaczny potencjał dalszej integracji gospodarczej w dziedzinie usług, produktów, opodatkowania oraz sektorów energetycznego i telekomunikacyjnego.

W 2018 r. obchodzona była również 50. rocznica przyjęcia rozporządzeń w sprawie swobody przepływu pracowników. Wśród inicjatyw mających na celu promowanie sprawiedliwej mobilności pracowników na obszarze całej wspólnoty, należy wskazać wniosek dotyczący utworzenia Europejskiego Urzędu ds. Pracy, do którego zadań należałoby informowanie obywateli i przedsiębiorstw o możliwościach zamieszkania, pracy lub prowadzenia działalności gospodarczej w innym państwie UE, dbałość o skuteczne i sprawiedliwe egzekwowania przepisów oraz prowadzenie mediacji w przypadku sporów o charakterze transgranicznym ${ }^{21}$. Odnosząc się do przedstawionego w marcu 2018 r. projektu rozporządzenia w sprawie ustanowienia Europejskiego Urzędu ds. Pracy, rząd polski pozytywnie ocenił koordynacyjną rolę oraz zapowiadane działania na rzecz promocji rozwoju inicjatyw wspierania mobilności transgranicznej obywateli,

$20 \operatorname{COM}(2018) 772$ final.

$21 \operatorname{COM}(2018) 131$ final. 
w tym ukierunkowane programy mobilnościowe, ale jednocześnie wskazał na niebezpieczeństwo dublowania kompetencji innych organów przez projektowany urząd, co może wpłynąć negatywnie na przejrzystość prawną oraz racjonalność podejmowanych działań. Wątpliwości wzbudziła też wartość dodana proponowanych rozwiązań, $\mathrm{w}$ tym związane $\mathrm{z}$ wprowadzeniem proponowanych regulacji koszty i obciążenia biurokratyczne, jak również możliwe naruszenia zasad traktatowych związanych z przyjęciem rozporządzenia w sprawie ustanowienia Europejskiego Urzędu ds. Pracy.

W październiku 2018 r. przyjęte zostało rozporządzenie w sprawie utworzenia jednolitego portalu cyfrowego, którego celem jest m.in. redukcja obciążeń administracyjnych dla obywateli i przedsiębiorstw poprzez umożliwienie im przeprowadzenia najważniejszych formalności administracyjnych online. Zakłada się, że w przyszłości 21 kluczowych procedur administracyjnych (m.in. wydanie aktu urodzenia czy zarejestrowanie pojazdu) będzie dostępne w formie elektronicznej.

Wśród inicjatyw podjętych w 2018 r. w celu dalszej budowy silnej i innowacyjnej bazy przemysłowej należy wskazać m.in. utworzenie nagrody w wysokości $10 \mathrm{mln}$ euro za innowacyjne baterie $\mathrm{w}$ pojazdach, zorganizowanie pierwszego Przemysłowego Forum Czystej Energii poświęconego inicjatywom w zakresie baterii, odnawialnych źródeł energii i budownictwa, a także przeprowadzenie pierwszego forum wysokiego szczebla pt. „Przemysł 2030” (zalecenia ekspertów dotyczące wizji przyszłości europejskiego przemysłu zostaną przedstawione latem 2019 r.).

Ważnym elementem sprawnie funkcjonującego jednolitego rynku są skuteczne i sprawiedliwe przepisy podatkowe. Mając to na uwadze, w celu uproszczenia opodatkowania i zwiększenia jego odporności na oszustwa w marcu $2018 \mathrm{r}$. ministrowie finansów państw UE przyjęli przepisy mające na celu zapobieganie transgranicznemu planowaniu podatkowemu. Zgodnie $\mathrm{z}$ przyjętym harmonogramem wdrażania nowych przepisów od lipca 2020 r. pośrednicy, tacy jak: doradcy podatkowi, księgowi i prawnicy, którzy opracowują lub propagują rozwiązania z zakresu planowania podatkowego, będą musieli zgłaszać organom podatkowym rozwiązania uznawane za potencjalnie agresywne. Ponadto w maju Komisja przedstawiła szczegółowe środki techniczne mające na celu wdrożenie głównych zasad opodatkowania handlu między państwami UE.

Dążąc do zapewnienia lepszej jakości usług finansowych, Parlament Europejski, Rada i Komisja osiągnęły porozumienie, zgodnie z którym tanie przelewy w euro oraz bardziej sprawiedliwe przeliczanie walut będzie dostępne również dla mieszkańców i przedsiębiorców spoza strefy euro. Przedstawiony został też wniosek w sprawie nowych unijnych przepisów dotyczących ubezpieczeń komunikacyjnych, którego celem jest zwiększenie ochrony ofiar wypadków samochodowych oraz praw posiadaczy polis ubezpieczeniowych, w tym zagwarantowanie, że ofiary wypadków drogowych otrzymają należne im pełne odszkodowanie, nawet gdy ubezpieczyciel okaże się niewypłacalny. 
Zapewnienie równych warunków działania na jednolitym rynku jest jednym z kluczowych elementów pogłębionego i bardziej sprawiedliwego rynku wewnętrznego UE. Służy temu w szczególności przeciwdziałanie kartelom m.in. przez nakładanie dużych kar pieniężnych (np. 395 mln euro na czterech morskich przewoźników samochodów, 254 mln euro na ośmiu producentów kondensatorów) oraz kontrolowanie, czy poszczególne państwa członkowskie nie przyznają wybranym przedsiębiorstwom lepszych warunków pod względem podatkowym (np. w czerwcu 2018 r. Komisja zobowiązała Luksemburg do odzyskania od grupy Engie ok. $120 \mathrm{mln}$ euro niezapłaconego podatku).

Istotną rolę we wspieraniu innowacyjnej i konkurencyjnej gospodarki odgrywa ochrona praw własności intelektualnej oraz zwalczanie podrabiania produktów. W tym zakresie Komisja zaproponowała m.in. dostosowanie przepisów dotyczących własności intelektualnej przedsiębiorstw farmaceutycznych z UE, aby podnieść ich konkurencyjność na rynkach światowych. Z kolei przedsiębiorstwa reprezentujące sektor reklamy podpisały dobrowolne porozumienie, którego celem jest obniżenie przychodów z reklam, jakie uzyskują strony internetowe lub aplikacje mobilne, które naruszają prawa autorskie lub rozpowszechniają podrobione produkty.

Rynek zamówień publicznych w UE jest szacowany na ponad $14 \% \mathrm{PKB}$, co oznacza, że co roku ponad 250 tys. organów administracji publicznej wydaje ok. 2 bln euro. Komisja opublikowała wytyczne mające na celu zachęcić nabywców publicznych do korzystania z zamówień publicznych jako instrumentu stymulowania inwestycji, a także wydała zalecenia dla organów krajowych mające na celu wspieranie sektora MŚP oraz ułatwianie małym i średnim podmiotom udziału w postępowaniach o udzielanie zamówień w dziedzinie obronności. Ponadto w ramach wieloletnich ram finansowych na lata 2021-2027 Komisja zaproponowała nowy specjalny program o wartości 4 mld euro, którego celem jest umożliwienie małym i średnim przedsiębiorstwom czerpania ze wszystkich korzyści oferowanych przez prawidłowo funkcjonujący jednolity rynek oraz wzmocnienie pozycji i ochrony konsumentów.

- Pogłębiona i bardziej sprawiedliwa unia gospodarcza i walutowa

W 2018 r. nastąpiło ukończenie budowy unii bankowej, co stanowiło kolejny etap pogłębienia integracji w ramach unii gospodarczej i walutowej. W grudniu przywódcy państw UE poparli ostatecznie plan wprowadzenia wspólnego mechanizmu ochronnego $\mathrm{w}$ ramach jednolitego funduszu restrukturyzacji i uporządkowanej likwidacji, który będzie działać za pośrednictwem Europejskiego Mechanizmu Stabilności. Mechanizm ten będzie uruchamiany w sytuacjach nadzwyczajnych w stosunku do instytucji finansowych o dużym znaczeniu gospodarczym.

Komisja Europejska przedstawiła też dwie propozycje rozwiązań dla sektora bankowego. Pierwsza z nich dotyczyła puli kredytów zagrożonych nadal występujących w portfelach bankowych wraz z propozycjami rozwiązań zapobiegają- 
cych ich akumulacji w przyszłości. Druga propozycja dotyczyła ram prawnych dla papierów wartościowych zabezpieczonych obligacjami skarbowymi, które umożliwią dywersyfikację portfeli papierów wartościowych banków. W analizowanym roku nie udało się jednak zakończyć prac nad dwoma innymi projektami, tj. przyśpieszoną pozasądową egzekucją kredytów zabezpieczonych oraz wtórnym rynkiem obrotu kredytami zagrożonymi.

Corocznemu badaniu poddano także stopień spełnienia kryteriów wejścia do strefy euro siedmiu państw członkowskich UE, które zobowiązały się przyjąć euro, ale jeszcze tego nie uczyniły ( $w$ tym Polski). W wyniku oceny stwierdzono, że żadne z państw nie spełnia wszystkich wymaganych warunków członkostwa. Stwierdzono, że Bułgaria i Chorwacja spełniają wszystkie kryteria konwergencji z wyjątkiem kryterium kursu walutowego, a wyłącznie prawodawstwo Chorwacji jest w pełni zgodne z zasadami unii gospodarczej i walutowej.

Komisja nadal wspiera reformy strukturalne w państwach członkowskich UE, tak aby ich gospodarki stały się bardziej stabilne, produktywne i odporne na wstrząsy oraz w większym stopniu sprzyjały włączeniu społecznemu. W tym celu utworzyła w 2015 r. Służbę ds. Wspierania Reform Strukturalnych. W 2018 r. Parlament Europejski i Rada zatwierdziły zwiększenie budżetu programu wspierania reform strukturalnych do 222,8 mln euro na okres do $2020 \mathrm{r}$.

- Zrównoważona i postępowa polityka handlowa w celu wykorzystania możliwości płynących z globalizacji

Unia Europejska pozostaje jedną z najbardziej otwartych gospodarek na świecie, dbając o utrzymanie wielostronnego systemu handlowego opartego na zasadach jednakowych dla wszystkich jego uczestników. Podstawowym forum pozwalającym na utrzymanie tego systemu jest Światowa Organizacja Handlu (WTO), którą UE aktywnie wykorzystuje, starając się jednocześnie wypracowywać nowe rozwiązania w odpowiedzi na pojawiające się zagrożenia dla wolnego handlu. We wrześniu 2018 r. UE przedstawiła dokument koncepcyjny w sprawie reformy WTO, podejmując takie kwestie, jak: aktualizacja przepisów dotyczących dotacji i przymusowych transferów technologii, potrzeba większej przejrzystości, przezwyciężenie impasu w powoływaniu członków Organu Apelacyjnego (WTO Appellate Body). Najważniejszymi problemami zgłaszanymi przez UE na forum WTO było kontrolowanie dotacji, które szkodzą konkurencji, w odniesieniu nie tylko do towarów, ale także usług oraz sprawiedliwy dostęp do zamówień publicznych.

W tym ostatnim obszarze finalizowane są prace nad rozporządzeniem w sprawie dostępu towarów i usług z państw trzecich do rynku wewnętrznego Unii w zakresie zamówień publicznych oraz procedur wspierających negocjacje dotyczące dostępu unijnych towarów i usług do rynków zamówień publicznych państw trzecich ${ }^{22}$. Najważniejszym narzędziem wprowadzanym przez propo-

$22 \operatorname{COM}(2016) 34$ final. 
nowane rozporządzenie jest zastosowanie korekty ceny wobec niektórych ofert składanych w postępowaniu o zamówienie publiczne w zależności od kraju pochodzenia wykonawców lub dostawców towarów lub usług.

Wyraźny postęp nastąpił w zakresie wprowadzenia przepisów dotyczących monitorowania bezpośrednich inwestycji zagranicznych pod kątem bezpieczeństwa i porządku publicznego ${ }^{23}$. Mechanizm monitorowania bezpośrednich inwestycji zagranicznych umożliwi wzajemne informowanie się państw członkowskich i Komisji Europejskiej o inwestycjach, które mogą stanowić zagrożenie dla bezpieczeństwa lub porządku publicznego. Pozwoli on także na ich monitorowanie przez Komisję tych inwestycji, które mogą mieć istotny wpływ na projekty lub programy leżące w interesie UE (np. dotyczące sektora energetycznego, zaopatrzenia w surowce i bezpieczeństwa cybernetycznego), a także inwestycji współfinansowanych z budżetu unijnego.

Unia kontynuuje negocjacje w sprawie umów o wolnym handlu z poszczególnymi krajami. W 2018 r. osiągnięto porozumienie w sprawie nowej umowy handlowej z Meksykiem oraz podpisano umowę handlową z Japonią. Nadal prowadzone są rozmowy z czterema państwami założycielami bloku handlowego Mercosur (Argentyną, Brazylią, Paragwajem i Urugwajem) oraz z Chile, a nowe negocjacje rozpoczęto z Australią i Nową Zelandią. Obecnie UE związana jest umowami handlowymi z 70 partnerami, co daje ok. 40\% światowego PKB.

Uwagi wymagają relacje handlowe ze Stanami Zjednoczonymi. W czerwcu 2018 r. Stany Zjednoczone nałożyły cła na produkty ze stali i aluminium z UE, które zdaniem UE były nieuzasadnione i nielegalne. W efekcie UE wprowadziła środki równoważące na eksport ze Stanów Zjednoczonych. W celu rozstrzygnięcia kontrowersji powołana została grupa robocza, której zadaniem jest wypracowanie rozwiązania pozwalającego na ściślejszą współpracę w zakresie regulacji, zniesienie ceł na produkty przemysłowe (oprócz samochodów), ułatwienie handlu soją oraz zwiększenie handlu skroplonym gazem ziemnym. Od czasu powstania grupy miały miejsce cztery posiedzenia na szczeblu politycznym, dzięki czemu można było odnotować pierwsze pozytywne rezultaty: nastąpiło podpisanie kilku długoterminowych umów między przedsiębiorstwami obu stron na dostawy skroplonego gazu ziemnego; USA zgodziły się złagodzić swoje wymogi dotyczące uzyskiwania zezwoleń na eksport skroplonego gazu ziemnego do UE; amerykańscy eksporterzy blisko dwukrotnie zwiększyli swój udział w unijnym rynku soi. Jednocześnie obie strony zgodziły się nie wprowadzać nowych ceł we wzajemnej wymianie handlowej.

Dużej aktywności wymaga obrona systemu międzynarodowego handlu zgodnie z zasadami WTO. Opublikowane w czerwcu 2018 r. sprawozdanie roczne KE w sprawie barier w handlu i inwestycjach wykazało, że w 2017 r. eksporterzy z UE

$23 \operatorname{COM}(2017) 487$ final. W marcu 2019 r. rozporządzenie zostało przyjęte przez Radę i ma wejść w życie w kwietniu. 
napotkali 396 barier w ponad 57 krajach świata, co stanowi znaczny wzrost w stosunku do roku 2016. Strategia dostępu do rynku opracowana przez Komisję pozwoliła na wyeliminowanie 45 przeszkód mających negatywny wpływ na eksport UE o wartości 8,2 mld euro, tj. usunięto ponad dwukrotnie więcej barier niż w 2016 r.

- Obszar sprawiedliwości i przestrzegania praw podstawowych, którego podstawą jest wzajemne zaufanie

Unia Europejska kontynuowała wysiłki na rzecz budowy obszaru sprawiedliwości i przestrzegania praw podstawowych opartego na wzajemnym zaufaniu. Podjęte w tym zakresie inicjatywy zostały skoncentrowane na prowadzeniu działań w następujących obszarach szczegółowych:

- zwalczanie terroryzmu i przestępczości, w tym prania pieniędzy,

- wymiar sprawiedliwości w sprawach cywilnych,

- prawo spółek i dostęp do informacji o przedsiębiorstwach,

- wzmocnienie ochrony danych osobowych,

- prawa podstawowe i systemy sądowe,

- ochrona praw i zwalczanie dyskryminacji,

- obywatelstwo Unii Europejskiej,

- wybory do Parlamentu Europejskiego,

- ochrona konsumentów,

- Unijny Mechanizm Ochrony Ludności (rescEU),

- długoterminowy budżet UE na lata 2021-2027.

W 2018 r. weszły w życie trzy dyrektywy służące wzmocnieniu walki z terroryzmem i poważną przestępczością: 1) dyrektywa UE w sprawie danych dotyczących przelotu pasażera (PNR); 2) dyrektywa w sprawie zwalczania terroryzmu oraz 3) dyrektywa w sprawie kontroli nabywania i posiadania broni. W ramach budowy unii bezpieczeństwa Komisja przedstawiła wniosek ukierunkowany na zablokowanie terrorystom dostępu do finansowania przez przyspieszenie dostępu organów ścigania do informacji finansowych niezbędnych do prowadzenia dochodzeń w sprawach poważnych przestępstw oraz wzmocnienie współpracy między krajowymi organami ścigania i krajowymi jednostkami analityki finansowej, a także Europolem. Komisja zaproponowała również przepisy dotyczące dostawców usług hostingowych mające zapewnić usuwanie treści o charakterze terrorystycznym w ciągu godziny od pojawienia się w sieci. W związku z potrzebą rozszerzenia kompetencji Prokuratury Europejskiej w zakresie zwalczania transgranicznego terroryzmu we wszystkich państwach członkowskich Komisja wezwała Radę Europejską do zmiany art. 86 TFUE.

Komisja zaproponowała także nowe przepisy dla organów sądowych i organów ścigania, mające ułatwić dostęp do elektronicznego materiału dowodowego znajdującego się w posiadaniu dostawców usług z siedzibą w innych krajach niezależnie od miejsca ich przechowywania w Unii. 
W dniu 14 listopada 2018 r. przyjęto rozporządzenie w sprawie zabezpieczania i konfiskaty aktywów za granicą. Nowe regulacje ułatwią transgraniczne odzyskiwanie mienia pochodzącego z przestępstw, pozwolą na bardziej skuteczne zabezpieczanie i konfiskatę nielegalnych środków oraz będą chronić prawa ofiar do odszkodowania. Ponadto UE postanowiła usprawnić ramy prawne europejskiego systemu przekazywania informacji z rejestrów karnych, dzięki czemu państwa członkowskie uzyskały wsparcie w identyfikacji obywateli państw trzecich skazanych za przestępstwa.

Przedmiotem podejmowanych inicjatyw była także kwestia przeciwdziałania praniu pieniędzy i wykorzystywania ich do finansowania działalności terrorystycznej. W lipcu 2018 r. weszły w życie nowe przepisy, ukierunkowane na uniemożliwienie wykorzystywania unijnych systemów finansowych do prania pieniędzy lub finansowania działalności terrorystycznej. We wrześniu Komisja przedstawiła wniosek w sprawie zwiększenia uprawnień nadzorczych przyznanych instytucjom finansowym UE. Przewidziano w nim w szczególności wzmocnienie mandatu Europejskiego Urzędu Nadzoru Bankowego do działania w zakresie nadzoru nad praniem pieniędzy w sektorze finansowym. W październiku UE postanowiła zaostrzyć środki prawnokarne służące przeciwdziałaniu praniu pieniędzy. Nowa dyrektywa zakłada ujednolicenie przepisów dotyczących przestępstw polegających na praniu pieniędzy i grożących za nie sankcji.

Ponadto Komisja przyjęła rozporządzenie delegowane w sprawie przyjęcia regulacyjnych standardów technicznych dotyczących kryteriów wyznaczania centralnych punktów kontaktowych przez dostawców usług płatniczych i emitentów pieniądza elektronicznego oraz przepisów dotyczących funkcji pełnionych przez takie punkty.

W obszarze wymiaru sprawiedliwości w sprawach cywilnych skoncentrowano się na poprawie współpracy sądowej. Kierując się intencją zapewnienia obywatelom i przedsiębiorstwom tańszego, bardziej skutecznego i łatwiejszego dostępu do wymiaru sprawiedliwości w sprawach cywilnych, Komisja przyjęła dwa wnioski dotyczące modernizacji i cyfryzacji współpracy sądowej w odniesieniu do doręczania dokumentów i przeprowadzania dowodów.

W grudniu Rada i Parlament Europejski osiągnęły porozumienie w sprawie proponowanych przepisów dotyczących postępowania upadłościowego, które pozwolą na ustanowienie systemów restrukturyzacyjnych i zapewnienie przedsiębiorcom drugiej szansy. Inicjatywa ma na celu zwiększenie szans przedsiębiorstw na przeprowadzenie restrukturyzacji na wczesnym etapie, aby można było zapobiec upadłości oraz uniknąć zwalniania pracowników. Również w grudniu Rada osiągnęła porozumienie polityczne w sprawie proponowanej nowelizacji rozporządzenia Bruksela II bis zakładającej potrzebę aktualizacji przepisów chroniących dzieci w transgranicznych sporach rodzinnych oraz przyspieszenie postępowań. 
Tworząc regulację rynku spółek i dostępu do informacji o przedsiębiorstwach, Komisja zaproponowała nowe przepisy dotyczące stosowania narzędzi i procesów cyfrowych w prawie spółek oraz transgranicznego przekształcania, łączenia i podziału spółek. W założeniu mają one umożliwić przedsiębiorstwom korzystanie $\mathrm{z}$ narzędzi cyfrowych w kontaktach z organami publicznymi oraz zapewnić zharmonizowaną procedurę w przypadku restrukturyzacji lub przenoszenia działalności w obrębie jednolitego rynku.

W związku z potrzebą wzmocnienia ochrony danych osobowych obywateli UE i przedsiębiorstw w maju weszło w życie ogólne rozporządzenie o ochronie danych. Natomiast w grudniu weszły w życie nowe przepisy o ochronie danych dotyczące instytucji, organów i jednostek organizacyjnych UE.

W obszarze praw podstawowych i systemów sądowych UE skupiła się na poprawie skuteczności systemów wymiaru sprawiedliwości oraz utrzymaniu praworządności. Opierając się na unijnej tablicy wyników wymiaru sprawiedliwości i europejskim semestrze, Komisja wydała w lipcu zalecenia dla Chorwacji, Włoch, Cypru, Portugalii i Słowacji. We wrześniu skierowała do TSUE sprawę przeciwko Polsce, zarzucając naruszenie zasady niezawisłości sędziowskiej na skutek obniżenia wieku przejścia w stan spoczynku sędziów Sądu Najwyższego. Trybunał Sprawiedliwości zarządził środki tymczasowe podtrzymujące wszystkie wnioski Komisji do czasu wydania prawomocnego wyroku. Ponadto w kontekście nowego długoterminowego budżetu UE Komisja zdecydowała się przedstawić wniosek dotyczący rozporządzenia w sprawie ochrony budżetu Unii w przypadku niedociągnięć w zakresie praworządności w państwach członkowskich.

Unia kontynuowała także działania na rzecz podniesienia efektywności ochrony praw człowieka i zwalczania dyskryminacji. W sprawozdaniu ze stosowania Karty praw podstawowych UE za 2017 r. zwrócono uwagę na potrzebę zapewnienia skuteczniejszej reakcji na przestępstwa $\mathrm{z}$ nienawiści i przemoc wobec kobiet. Jak wynika $\mathrm{z}$ trzeciej oceny stosowania unijnego Kodeksu postępowania w zakresie zwalczania nielegalnego nawoływania do nienawiści w internecie, opublikowanej w styczniu 2018 r., dokonano dalszych postępów w zakresie szybkiej weryfikacji i usuwania rasistowskiego i ksenofobicznego nawoływania do nienawiści na platformach internetowych.

Realizując europejską strategię w sprawie niepełnosprawności, Komisja przedstawiła wniosek dotyczący europejskiego aktu w sprawie dostępności do produktów i usług codziennego użytku, takich jak: telefony komórkowe, komputery, e-booki, handel elektroniczny i usługi bankowe. UE w dalszym ciągu promowała różnorodność poprzez wspieranie inicjatywy „Kart różnorodności”. Kontynuowano również wdrażanie wykazu działań na rzecz postępów w zakresie równouprawnienia osób LGBTI. Komisja opublikowała też szczegółową ocenę unijnych ram dotyczących krajowych strategii integracji Romów na lata 2011-2020.

Aby rozwiązać problem zróżnicowania wynagrodzenia ze względu na płeć, Komisja rozpoczęła wdrażanie planu działania na rzecz osiągnięcia równości 
wynagrodzeń dla mężczyzn i kobiet. Ponadto UE zakończyła proces przystąpienia do konwencji stambulskiej Rady Europy o zapobieganiu i zwalczaniu przemocy wobec kobiet i przemocy domowej.

Kierując się intencją zagwarantowania wolności wypowiedzi i wolności mediów, Komisja zaproponowała ogólnounijne normy ochrony sygnalistów zgłaszających naruszenia przepisów UE mogących poważnie zaszkodzić interesowi publicznemu.

W maju 2018 r. obywatele Unii Europejskiej zyskali ochronę konsularną dzięki uprawnieniom do korzystania z pomocy ambasad innych państw członkowskich UE w kraju poza UE. W celu zwiększenia bezpieczeństwa dokumentów i usprawnienia stosowanych procedur Komisja przedstawiła także propozycję ulepszeń w przepisach dotyczących unijnych, tymczasowych dokumentów podróży. Komisja zaproponowała ulepszenie zabezpieczeń dowodów tożsamości obywateli UE, dokumentów pobytowych i kart pobytowych członków rodzin spoza UE.

W obliczu zwiększonego ryzyka wystąpienia kampanii dezinformacyjnych i cyberataków Komisja przyjęła we wrześniu 2018 r. pakiet środków w celu wsparcia władz państw członkowskich i innych zainteresowanych stron we wspólnych wysiłkach na rzecz zapewnienia wolnych i uczciwych wyborów do Parlamentu Europejskiego w 2019 r.

W związku z potrzebą zapewnienia ochrony interesów konsumentów w UE Komisja zaproponowała nowy ład dla konsumentów zakładający powstanie europejskiego systemu zbiorowego dochodzenia roszczeń w przypadkach szkód poniesionych przez grupy konsumentów oraz wyposażenie organów ochrony konsumentów w państwach członkowskich w większe uprawnienia do nakładania kar na przedsiębiorców. Nowe przepisy mają również na celu dostosowanie praw konsumentów do nowych technologii, w tym wykorzystywanych na internetowych platformach handlowych. W odpowiedzi na potrzebę wyeliminowania nieuczciwych praktyk handlowych, polegających na wprowadzaniu do obrotu produktów prezentowanych jako identyczne, podczas gdy ich skład lub cechy charakterystyczne znacznie się różnią, Komisja doprecyzowała prawo UE, jak również opublikowała wspólną metodykę badań wdrażaną w ramach ogólnoeuropejskiej kampanii testowej. Zrealizowano także takie inicjatywy, jak: wzmocnienie praw uczestników imprez turystycznych, dokończenie tworzenia krajowych organów rozstrzygających spory konsumenckie, szybka wymiana informacji o produktach niebezpiecznych RAPEX oraz Safety Gate.

W 2018 r. Grecja, Szwecja, Łotwa i Portugalia skorzystały z Unijnego Mechanizmu Ochrony Ludności (rescUE), aby reagować na pożary lasów. Zebrane doświadczenia dowiodły potrzeby wzmocnienia i poprawy tego mechanizmu. W grudniu Parlament Europejski i Rada wstępnie uzgodniły wniosek Komisji w sprawie wzmocnienia rescUE. Wejście w życie proponowanych zmian planowane jest na pierwszą połowę 2019 r. 
W długoterminowym budżecie UE na lata 2021-2027 Komisja zaproponowała utworzenie Funduszu „Sprawiedliwość, Prawa i Wartości” z budżetem w wysokości 947 mln euro na okres siedmiu lat. Fundusz będzie koncentrował się na osobach i podmiotach, które przyczyniają się do podtrzymywania wspólnych wartości UE oraz jej praw i bogatej różnorodności.

- W kierunku nowej polityki w dziedzinie migracji

W 2018 r. kontynuowano realizację kompleksowego podejścia do polityki migracyjnej, obejmującego jednocześnie lepszą ochronę granic, współpracę z państwami trzecimi oraz aspekty wewnętrzne. W minionym roku nastąpiło ustabilizowanie napływów migracyjnych - liczba osób przybywających nielegalnie do UE spadła do poziomu sprzed kryzysu.

W kwestii ochrony granic i przeciwdziałania nielegalnym przepływom migracyjnym, w odniesieniu do zagadnienia zarządzania granicami, nadal prowadzono negocjacje w sprawie wniosku Komisji z 2017 r. dotyczącego nowelizacji kodeksu granicznego Schengen, którego celem jest dostosowanie do obecnych potrzeb przepisów regulujących przywracanie tymczasowych kontroli na granicach wewnętrznych. We wrześniu 2018 r. Komisja zaproponowała wzmocnienie do 2020 r. Europejskiej Agencji Straży Granicznej i Przybrzeżnej stałą służbą złożoną z 10 tys. pracowników operacyjnych (jej członkowie mieliby dysponować uprawnieniami wykonawczymi i własnym sprzętem). Do końca 2018 r. państwa członkowskie uzgodniły w Radzie niektóre elementy wniosku Komisji (przepisy dotyczące powrotów i współpracy z państwami trzecimi).

W październiku 2018 r. weszło w życie rozporządzenie ustanawiające Europejski System Informacji o Podróży oraz Zezwoleń na Podróż (ETIAS). System ten przewiduje przeprowadzanie wstępnej kontroli przesiewowej pod kątem bezpieczeństwa i ryzyka migracji. Kontroli tej będą poddawani podróżni korzystający z bezwizowego dostępu do strefy Schengen. Pełną operacyjność system ten ma osiągnąć do końca $2021 \mathrm{r}$.

Kontynuowano także prace nad wnioskami Komisji z 2016 r. dotyczącymi reformy Wspólnego Europejskiego Systemu Azylowego (WESA), m.in. nad rozporządzeniem o kwalifikowaniu, dyrektywą w sprawie warunków przyjmowania, rozporządzeniem w sprawie Agencji Unii Europejskiej ds. Azylu, rozporządzeniem Eurodac oraz rozporządzeniem w sprawie unijnych ram przesiedleń. Nie osiągnięto porozumienia w zakresie jednego z kluczowych elementów tej reformy, tj. projektu zmiany rozporządzenia dublińskiego. W związku z tym Komisja zaapelowała o utworzenie tymczasowego mechanizmu, który pozwoliłby na wypracowanie i przyjęcie doraźnego rozwiązania do czasu osiągnięcia porozumienia co do całości reformy systemu azylowego. We wrześniu 2018 r. Komisja zaproponowała dalsze rozszerzenie uprawnień Agencji Unii Europejskiej ds. Azylu oraz będących do jej dyspozycji narzędzi i budżetu w celu udzielania państwom członkowskim na ich wniosek pełniejszej pomocy w ramach międzynarodowej procedury ochrony. 
Nadal realizowany był „Plan działania na rzecz integracji obywateli państw trzecich” z 7 czerwca 2016 r., który stanowi ramy wspierające wysiłki państw członkowskich w zakresie opracowywania i wzmacniania polityki integracyjnej przez wsparcie finansowe i wytyczne dotyczące najlepszych praktyk.

- Silniejsza pozycja na arenie międzynarodowej

Unia Europejska zauważa, że sytuacja na świecie staje się coraz bardziej niestabilna, a porządek międzynarodowy opierający się na roli instytucji międzynarodowych jest coraz częściej podważany. Mimo tych niekorzystnych okoliczności UE stoi na stanowisku, że działania dyplomatyczne są najskuteczniejszym sposobem na zapewnienie bezpieczeństwa i pokoju i będzie dążyć do promowania pokoju, stabilności i bezpieczeństwa, wspierania współpracy na rzecz rozwoju, przestrzegania praw człowieka i praworządności oraz reagowania na kryzysy humanitarne.

W 2018 r. UE przeznaczyła na pomoc humanitarną - służącą ratowaniu życia w przypadku katastrof naturalnych i konfliktów zbrojnych - ponad 1 mld euro, co oznacza, że była największym darczyńcą na świecie. Była również największym darczyńcą w zakresie współpracy rozwojowej (a więc działań na rzecz zniwelowania różnic w poziomie rozwoju dzięki poprawie jakości życia w regionach słabiej rozwiniętych). Podejmowała także działania mające wzmocnić jej rolę w sferze bezpieczeństwa. W tym celu m.in. zaproponowano rozbudowę Europejskiego Funduszu Obronnego, przyjęto 34 projekty w dziedzinie obronności w ramach stałej współpracy strukturalnej oraz przyjęto nowy Europejski Instrument na rzecz Pokoju wspierający współdziałanie w dziedzinie obronności.

Głównymi podmiotami działań w zakresie polityki zagranicznej UE były: państwa wschodniego sąsiedztwa i Rosji, Bałkanów Zachodnich w kontekście procesu rozszerzenia, Turcji, Afryki, Ameryki Północnej i Łacińskiej, Azji i regionu Pacyfiku oraz Bliskiego Wschodu. Wśród tych działań na szczególną uwagę zasługuje sytuacja w relacjach $\mathrm{z}$ regionem Bałkanów Zachodnich. W lutym 2018 r. KE opublikowała strategię dla Bałkanów Zachodnich na rzecz wiarygodnej perspektywy rozszerzenia oraz zwiększenia zaangażowania, w której potwierdzono, że perspektywa członkostwa powinna być główną siłą napędową reform i modernizacji, przedstawiono plan 57 działań na lata 2018-2020 opartych na sześciu inicjatywach (praworządność, bezpieczeństwo i migracja, rozwój społeczno-gospodarczy, łączność, agenda cyfrowa oraz pojednanie i stosunki dobrosąsiedzkie) i określono rok 2025 jako realny termin rozszerzenia. Z kolei w relacjach z państwami afrykańskimi należy odnotować wejście w życie we wrześniu 2018 r. nowych ram współpracy instytucjonalnej określonych mianem „Nowego sojuszu Afryka-Europa na rzecz zrównoważonych inwestycji i tworzenia miejsc pracy”. Porozumienie ma sprzyjać zwiększeniu liczby miejsc pracy i przyciągnięciu do Afryki inwestycji.

W budżecie na lata 2021-2017 przewiduje się zwiększenie środków przeznaczonych na działania zewnętrzne oraz na bezpieczeństwo i obronność. 
- Unia demokratycznych zmian

Z uwagi na przypadające w 2019 r. wybory do Parlamentu Europejskiego na szczególną uwagę zasługują inicjatywy podejmowane w tym zakresie. Należy wskazać na propozycje dotyczące wzmocnienia mechanizmu czołowych kandydatów (tzw. Spitzenkandidaten ${ }^{24}$, którzy mieliby być na etapie kampanii wyborczej do PE prezentowani jako kandydaci danej frakcji na przewodniczącego Komisji Europejskiej w nadchodzącej kadencji. Należy jednak zaznaczyć, że mechanizm ten może stanowić zarzewie konfliktu między Parlamentem Europejskim a Radą Europejską. Zgodnie bowiem z art. 17 ust. 7 TUE: uwzględniając wybory do Parlamentu Europejskiego i po przeprowadzeniu stosownych konsultacji, Rada Europejska, stanowiąc większością kwalifikowana, przedstawia Parlamentowi Europejskiemu kandydata na funkcje przewodniczacego Komisji. Kandydat ten jest wybierany przez Parlament Europejski większością głosów członków wchodzących w jego skład. Jeżeli nie uzyska on większości, Rada Europejska, stanowiąc większościa kwalifikowaną, przedstawia, w terminie miesiaca, nowego kandydata, który jest wybierany przez Parlament Europejski zgodnie z ta sama procedurą. Odwołując się do tego przepisu, podczas nieformalnego spotkania 27 głów państw lub szefów rządów (bez udziału Zjednoczonego Królestwa), które odbyło się 23 lutego 2018 r., członkowie Rady Europejskiej zgodnie uznali, że Rada nie może z góry zagwarantować, iż na stanowisko przewodniczącego Komisji Europejskiej zaproponuje jednego z głównych kandydatów zgłoszonych przed wyborami do Parlamentu Europejskiego, wskazanie kandydata stanowi bowiem autonomiczną kompetencję Rady Europejskiej.

W odniesieniu do zasad pomocniczości i proporcjonalności należy odnotować przedłożenie ostatecznego sprawozdania grupy zadaniowej ds. zasad pomocniczości, proporcjonalności i „robić mniej, ale efektywniej”. Grupa zadaniowa stwierdziła, że potrzebny jest nowy sposób pracy, jeśli chodzi o zasady pomocniczości i proporcjonalności, który umożliwi władzom lokalnym i regionalnym oraz parlamentom narodowym bardziej skuteczny wkład w kształtowanie polityki UE i opracowywanie nowych przepisów. Grupa zadaniowa zaleca również, aby w elastyczny sposób stosować termin 8 tygodni dla parlamentów narodowych na przedstawienie ich opinii na temat projektów aktów prawnych UE oraz rozważyć możliwość wydłużenia w przyszłości do 12 tygodni czasu dostępnego na przedstawienie opinii. W 2018 r. wpłynęło ogółem 570 opinii od parlamentów narodowych, w tym 37 uzasadnionych opinii w ramach mechanizmu kontroli zasady pomocniczości, w których twierdzono, że akty ustawodawcze przedstawione przez Komisję nie są zgodne z zasadą pomocniczości.

Dążąc do usprawnienia procesu podejmowania decyzji, we wrześniu $2018 \mathrm{r}$. Komisja zaproponowała częstsze korzystanie z głosowania większością kwalifi-

24 Zob. zalecenie Komisji (UE) 2018/234 z 14 lutego 2018 r. w sprawie uwydatnienia europejskiego charakteru i usprawnienia procesu wyborów do Parlamentu Europejskiego w 2019 r., C/2018/0900. 
kowaną w niektórych obszarach wspólnej polityki zagranicznej i bezpieczeństwa UE. W ramach programu sprawności i wydajności regulacyjnej (REFIT) Komisja zrealizowała ponad 150 inicjatyw ukierunkowanych na uproszczenie prawodawstwa i zmniejszenie obciążeń administracyjnych.

W odniesieniu do praworządności w sprawozdaniu zwraca się uwagę, że w 2018 r. Komisja w dalszym ciągu odnosiła się do wyzwań w tym zakresie w niektórych państwach UE, w szczególności na Węgrzech i w Polsce. Wobec Polski KE zainicjowała procedurę przewidzianą w art. 7 ust. 1 TUE. Zgodnie z tym przepisem, na uzasadniony wniosek jednej trzeciej państw członkowskich, Parlamentu Europejskiego lub Komisji Europejskiej, Rada, stanowiąc większością czterech piątych swych członków po uzyskaniu zgody Parlamentu Europejskiego, może stwierdzić istnienie wyraźnego ryzyka poważnego naruszenia przez państwo członkowskie wartości, o których mowa w artykule 2 TUE. $\mathrm{Na}$ chwilę sporządzenia opinii uchwała Rady w tej sprawie nie została podjęta. Ponadto 24 września 2018 r. Komisja Europejska podjęła decyzję o pozwaniu Polski przed Trybunał Sprawiedliwości UE pod zarzutem naruszenia zasady niezawisłości sędziowskiej. Komisja zwróciła się jednocześnie do Trybunału Sprawiedliwości o zarządzenie środków tymczasowych do chwili wydania orzeczenia w tej sprawie. Trybunał Sprawiedliwości zarządził środki tymczasowe postanowieniem z 17 grudnia 2018 r. w sprawie C-619/18 R Komisja Europejska v Polska. Wydanie opinii rzecznika generalnego w sprawie głównej jest zaplanowane na 11 kwietnia 2019 r.

Kolejną inicjatywą podjętą przez KE w zakresie praworządności było przedłożenie propozycji powiązania między finansowaniem UE a praworządnością. W ocenie KE: poszanowanie praworządności jest niezbędnym warunkiem wstępnym należytego zarządzania finansami i skutecznego unijnego finansowania. Komisja proponuje zatem wprowadzenie nowego mechanizmu chroniacego budżet UE przed ryzykiem finansowym związanym zogólnymi niedociagnięciami $w$ zakresie praworządności w państwach członkowskich. Nowe narzędzia pozwoliłyby Unii na zawieszenie, zmniejszenie lub ograniczenie dostępu do finansowania ze środków unijnych $w$ sposób proporcjonalny do charakteru, wagi i zakresu niedociagnięć $w$ dziedzinie praworządności.

W odniesieniu do Europejskiej Inicjatywy Obywatelskiej należy zaznaczyć, że w 2018 r. Komisja zarejestrowała siedem nowych inicjatyw. W dniu 12 grudnia 2018 r. osiągnięto porozumienie polityczne z Parlamentem Europejskim i Radą w sprawie reformy europejskiej inicjatywy obywatelskiej na podstawie wniosku Komisji przyjętego w 2017 r.

\section{- Wystąpienie Zjednoczonego Królestwa z Unii Europejskiej}

Odrębny fragment sprawozdania dotyczy wystąpienia Zjednoczonego Królestwa z Unii Europejskiej. Do istotnych działań podjętych przez UE w procedurze z art. 50 TUE, które miały miejsce w 2018 r., należy zaliczyć: 
- 29 stycznia 2018 r. - przyjęcie przez Radę (art. 50) decyzji upoważniającej do podjęcia negocjacji w sprawie uzgodnień przejściowych i wytycznych negocjacyjnych,

- 23 marca 2018 r. - przyjęcie przez Radę Europejską (art. 50) wytycznych w sprawie ram przyszłych stosunków między UE a Zjednoczonym Królestwem,

- 14 listopada 2018 r. - uzgodnienie przez negocjatorów Komisji i Zjednoczonego Królestwa umowy o wystąpieniu, dotyczącej warunków uporządkowanego wystąpienia Zjednoczonego Królestwa z UE,

- 22 listopada 2018 r. - uzgodnienie deklaracji politycznej, w której określono ramy przyszłych stosunków między UE a Zjednoczonym Królestwem,

- 25 listopada 2018 r. - formalne zatwierdzenie przez Radę Europejską (art. 50) umowy o wystąpieniu i przyjęcie deklaracji politycznej.

Zgodnie z art. 50 ust. 3 TUE traktaty przestają mieć zastosowanie do występującego państwa od dnia wejścia w życie umowy o wystąpieniu lub, w przypadku jej braku, dwa lata po notyfikacji zamiaru wystąpienia. W sytuacji braku ratyfikacji przez Zjednoczone Królestwo umowy o wystąpieniu wynegocjowanej z UE w dniu 29 marca 2019 r. powinno dojść do wystąpienia bez umowy (tzw. twardy brexit), chyba że Rada Europejska w porozumieniu ze Zjednoczonym Królestwem podejmie jednomyślnie decyzję o przedłużeniu tego okresu w trybie art. 50 ust. 3 TUE. W dniu 20 marca 2019 r. Zjednoczone Królestwo wystąpiło z wnioskiem o przedłużenie tego okresu do 30 czerwca 2019 r. ${ }^{25}$. Rada Europejska uzgodniła przedłużenie terminu do 22 maja 2019 r. pod warunkiem, że umowa o wystąpieniu zostanie zatwierdzona przez Izbę Gmin do 29 marca $2019 \mathrm{r}$. Jeżeli umowa o wystąpieniu nie zostanie zatwierdzona przez Izbę Gmin w tym terminie, Rada Europejska zgadza się na przedłużenie terminu do 12 kwietnia 2019 r. i oczekuje, że przed tą datą Zjednoczone Królestwo określi dalsze działania do rozważenia przez Radę Europejską ${ }^{26}$.

Niezależnie od powyższego, zgodnie z wyrokiem Trybunału Sprawiedliwości UE z 10 grudnia 2018 r. w sprawie C621/18, art. 50 TUE pozwala państwu członkowskiemu dopóty, dopóki nie wejdzie w życie umowa o wystąpieniu zawarta między danym państwem członkowskim a Unią Europejską lub, w przypadku braku takiej umowy, dopóki nie upłynie dwuletni okres przewidziany w ust. 3 tego samego artykułu, ewentualnie przedłużony zgodnie $\mathrm{z}$ tym ustępem, na jednostronne wycofanie notyfikacji zamiaru wystąpienia z UE, w sposób jednoznaczny i bezwarunkowy, w drodze pisma skierowanego do Rady Europejskiej,

25 List Premier Teresy May do Przewodniczącego Rady Europejskiej Donalda Tuska z 20 marca 2019 r., https://www.gov.uk/government/publications/prime-ministers-letter-to-president-tusk-20-march-2019 [dostęp 25 marca 2019 r.].

26 Konkluzje Rady Europejskiej (art. 50) z 21 marca 2019. 
po podjęciu przez to państwo członkowskie decyzji o wycofaniu notyfikacji zgodnie z jego wymogami konstytucyjnymi. Wycofanie to ma na celu potwierdzenie przynależności danego państwa członkowskiego do Unii Europejskiej na niezmienionych co do jego statusu państwa członkowskiego warunkach. Wycofanie takie kończy procedurę wystąpienia. Do momentu wystąpienia Zjednoczone Królestwo może więc jednostronnie odstąpić od zamiaru wystąpienia z UE. W związku z koniecznością rozważenia różnych scenariuszy rozwoju wypadków KE określiła zakres działań w ramach przygotowania do brexitu i planu awaryjnego, zasady leżące u ich podstaw oraz przedstawiła działania podjęte do tej pory.

\section{- Ocena zgodności działań UE, o których mowa w analizowanym dokumencie, z zasadą pomocniczości}

Dokument UE nie jest projektem aktu ustawodawczego UE i nie podlega ocenie pod kątem zgodności z zasadą pomocniczości w trybie protokołu nr 2 .

\section{- Ustosunkowanie się do informacji Rady Ministrów na temat opiniowanego dokumentu UE}

Rząd Rzeczypospolitej Polskiej przyjmuje do wiadomości przedstawiony dokument. Z uwagi na jego przekrojowy zakres rząd odnosi się jedynie do tych inicjatyw, które uważa za kluczowe z punktu widzenia interesów Polski.

Jako przykłady pozytywnych działań wskazuje między innymi:

- stałe uwzględnianie tematyki gospodarki o obiegu zamkniętym w pracach KE, - inicjatywy zmierzające do podniesienia poziomu profilaktyki chorób zakaźnych,

- kontynuację wspólnej polityki rolnej, przy czym rząd nie popiera pomysłu współfinansowania płatności bezpośrednich z budżetów narodowych,

- oferowanie transgranicznych możliwości uczenia się, studiowania oraz szkolenia,

- sprawiedliwe opodatkowanie gospodarki cyfrowej,

- promowanie ekologicznie czystych i energooszczędnych pojazdów transportu drogowego, będące elementem tzw. pakietu mobilności II,

- postęp w pracach nad ukończeniem unii bankowej oraz reformą Europejskiego Mechanizmu Stabilności,

- działania Komisji mające na celu reformę WTO, jak również finalizację negocjacji kolejnych umów handlowych z krajami i grupami krajów spoza UE,

- utrzymanie priorytetowego podejścia do kwestii bezpieczeństwa wewnętrznego UE, w tym walki z terroryzmem, również w przestrzeni internetowej (szczególnie istotnym dla Polski wątkiem w tym obszarze była kwestia dostępu do dowodów elektronicznych oraz kwestia retencji danych telekomunikacyjnych dla celów zapobiegania i zwalczania przestępczości), 
- przeciwdziałanie dyskryminacji konsumentów i uznanie stosowania podwójnej jakości produktów za praktykę handlową wprowadzającą w błąd,

- propozycje odnoszące się do poprawy skuteczności ochrony zewnętrznych granic UE i powrotu do prawidłowego funkcjonowania strefy Schengen.

Rząd krytycznie odnosi się natomiast do takich kwestii, jak:

- zmniejszenie finansowania czołowych polityk traktatowych, zwłaszcza wspólnej polityki rolnej oraz polityki spójności,

- uwarunkowanie wydatkowania środków UE od oceny przestrzegania praworządności, co, zdaniem rządu, ma charakter bardziej polityczny niż prawny czy ekonomiczny, a także powoduje ryzyko instrumentalizacji i powstania niepewności po stronie beneficjentów funduszy,

- zablokowanie prac nad projektem e-karty usługowej i dyrektywy notyfikacyjnej, jako że budzą one kontrowersje wśród państw członkowskich, oraz niekorzystne rozwiązania przyjęte $\mathrm{w}$ tzw. pakiecie mobilności I, które przyczyniają się do fragmentaryzacji jednolitego rynku, legitymizują działania protekcjonistyczne podejmowane przez niektóre państwa członkowskie oraz są krzywdzące dla przewoźników z państw położonych przy zewnętrznych granicach UE,

- pogłębiona harmonizacja polityk społecznych w UE, a zwłaszcza zbyt szeroki zakres działania Europejskiego Urzędu ds. Pracy,

- zaangażowanie Prokuratury Europejskiej w działania, mające usprawnić współpracę państw członkowskich w zwalczaniu przestępstw terrorystycznych o charakterze transgranicznym - Polska nie bierze udziału we wzmocnionej współpracy i uważa, że w pierwszej kolejności należy dokonać kompleksowej analizy możliwości współpracy Prokuratury Europejskiej w obszarze transgranicznej przestępczości terrorystycznej również z państwami nieuczestniczącymi w mechanizmie wzmocnionej współpracy oraz rozwijać potencjał operacyjny agencji unijnych (Europol i Eurojust), które w przeciwieństwie do Prokuratury Europejskiej obejmują wszystkie państwa członkowskie,

- obowiązkowa relokacja imigrantów w ramach UE oraz kontynuacja prac w zakresie tymczasowego mechanizmu solidarności - Polska podkreśla, że konsensus w sprawie mechanizmu solidarnościowego musi być oparty na szerokim wachlarzu dobrowolnych środków wsparcia,

- idea tzw. Spitzenkandidaten, tj. wystawianie przez europejskie partie polityczne w wyborach do PE kandydatów na przewodniczącego Komisji Europejskiej na listach wyborczych.

Szczegółowa analiza i ocena działań podejmowanych na forum Unii Europejskiej zawarta jest $\mathrm{w}$ stanowiskach rządu do poszczególnych projektów publikowanych przez Komisję Europejską. Ponadto aktywność Polski w poszczególnych obszarach polityki unijnej została przedstawiona w raportach dla Sejmu i Senatu przygotowanych na zakończenie prezydencji Bułgarii (styczeń-czerwiec 2018 r.) oraz prezydencji Austrii (lipiec-grudzień 2018 r.).

Stanowisko rządu jest wyczerpująco uzasadnione i nie budzi zastrzeżeń. 


\section{Opinia prawna}

\section{Podstawa prawna dokumentu UE}

Sprawozdanie Komisji jest dokumentem UE niebędącym projektem aktu prawnego UE. Zgodnie $\mathrm{z}$ art. 1 protokołu $\mathrm{nr} 1 \mathrm{w}$ sprawie roli parlamentów narodowych w Unii Europejskiej załączonego do Traktatu o Unii Europejskiej i Traktatu o funkcjonowaniu Unii Europejskiej jest ono dokumentem konsultacyjnym Komisji, przekazywanym parlamentom narodowym. Podstawę prawną sprawozdania stanowi art. 249 ust. 2 TFUE, zgodnie z treścią którego Komisja ma obowiązek publikowania corocznego ogólnego sprawozdania z działalności UE, rozpatrywanego przez Parlament Europejski.

Brak jest przesłanek, które uniemożliwiałyby przedstawienie przez Komisję sprawozdania w omawianym zakresie.

\section{Skutki prawne dokumentu UE}

Sprawozdanie jako dokument UE niebędący projektem aktu prawnego UE nie wywołuje skutków prawnych zarówno w świetle prawa polskiego, jak i prawa UE.

\section{Kwestie proceduralne}

- Procedura przyjmowania dokumentu

Przyjęcie sprawozdania nie jest związane z zachowaniem określonej, wynikającej z prawa traktatowego, procedury. Dokument UE został przyjęty przez Komisje Europejską 15 lutego 2019 r. i w tym samym dniu przekazany do Sejmu.

\section{- Działania Komisji do Spraw Unii Europejskiej}

Dokument nie jest projektem aktu prawnego UE, w związku z czym podstawą zwrócenia się Komisji do Spraw Unii Europejskiej (dalej: Komisja ds. UE) do Rady Ministrów o przedstawienie informacji na jego temat był art. 3 ust. 2 ustawy z 8 października 2010 r. o współpracy Rady Ministrów z Sejmem i Senatem w sprawach związanych z członkostwem Rzeczypospolitej Polskiej w Unii Europejskiej (Dz.U. 2013, poz. 1395; dalej: ustawa kooperacyjna). Komisja ds. UE wystąpiła 22 lutego 2019 r. do Rady Ministrów o przedstawienie informacji na temat analizowanego dokumentu.

Ustawa o współpracy nie precyzuje terminu udzielenia informacji zażądanej w opisanym trybie. Rada Ministrów przekazała Sejmowi informację na temat opiniowanego dokumentu 25 marca $2019 \mathrm{r}$.

$\mathrm{W}$ dalszym postępowaniu z opiniowanym dokumentem Komisja ds. UE nie jest ograniczona żadnymi terminami, poza tymi, które mogą wynikać z celowości podejmowanych przez nią działań. 


\section{Konkluzja}

Komisja Europejska corocznie przygotowuje sprawozdanie z działalności w roku poprzednim zgodnie $\mathrm{z}$ wymogami art. 249 ust. 2 TFUE. W sprawozdaniu Komisja informuje podmioty polityczne w krajach członkowskich oraz opinię publiczną o podjętych działaniach $\mathrm{w}$ trakcie całego roku. $\mathrm{Z}$ uwagi na bardzo szeroki zakres tego dokumentu ma on charakter raczej ogólny, hasłowo odnosząc się do opisywanych zagadnień. Pozwala jednak wyrobić sobie pogląd o całości problematyki podejmowanej przez Unię Europejską. Sprawozdanie za 2018 r. nie budzi kontrowersji, podejmowane działania odpowiadają przyjętemu przez KE na dany rok programowi prac, a większość opisywanych zagadnień pojawiała się w trakcie roku w postaci dokumentów szczegółowych i była omawiana na forum Sejmu. Sprawozdanie nie identyfikuje nowych zagadnień, co do których nie było informacji na etapie ich przygotowywania. 